\title{
Behavior of Cd during Coal Combustion: An Overview
}

\author{
Lucie Bartoňová *(D), Helena Raclavská ${ }^{\mathbb{D}}$, Bohumír Čech and Marek Kucbel $\mathbb{D}$ \\ ENET Centre, VSB-Technical University of Ostrava, 70800 Ostrava-Poruba, Czech Republic; \\ helena.raclavska@vsb.cz (H.R.); bohumir.cech@vsb.cz (B.Č.); marek.kucbel@vsb.cz (M.K.) \\ * Correspondence: lucie.bartonova@vsb.cz
}

Received: 3 September 2020; Accepted: 29 September 2020; Published: 2 October 2020

\begin{abstract}
Due to the unfavorable combination of its toxicity and high volatility, $\mathrm{Cd}$ is contained in most lists of potentially hazardous air pollutants with the greatest environmental and human-health concerns. The review paper evaluates the behavior of $\mathrm{Cd}$ during combustion (incineration) processes and its redistribution among condensed fractions (bottom ash/slag, fly ash) and volatilized fractions (that passes through most particulate control devices). The paper addresses all important effects of $\mathrm{Cd}$ interactions, such as presence of organic or inorganic chlorides, moisture levels, $\mathrm{S}, \mathrm{P}$ and $\mathrm{Na}$ concentrations, flue gas composition etc. Possibilities of using various adsorbents (either within in-furnace regime or applied in post-combustion zone) are evaluated as well. Special attention is paid to mitigating its emissions factors; decreasing $\mathrm{Cd}$ volatility and facilitating $\mathrm{Cd}$ retention are discussed with the view of various combustion (incineration) conditions and the feed fuel composition.
\end{abstract}

Keywords: cadmium; coal combustion; volatility; emissions; chlorine; retention; wastes

\section{Introduction}

Coal contains almost all the elements from the periodic chart. These elements differ by their concentrations, modes of occurrence, toxicity and behavior during coal combustion at power stations [1]. These factors influence not only the perspectives of their potential extractions from coal/ashes (such as rare earth elements (REE) [2,3], Y [4], Ge-Ga [5] etc.) but also their negative impact on the environment.

Environmental hazards are created by the coal characteristics (including the levels and associations of interacting species) and additionally by the operational conditions, such as the combustion technology, temperature, atmosphere, air-pollution control devices and proper use of desulfurization additives [6-8] or adsorbents [9-11].

Despite the progress achieved during the last decades, the decreasing of emissions of toxic elements is still a tough challenge. The overall environmental and human-health hazards of individual elements are given by their partitioning among bottom ash (slag), fly ash and emissions, as well as by their toxicity.

Wagner and Hlatshwayo [12] summarized and evaluated six lists of potentially hazardous air pollutants. All these lists contain $\mathrm{Hg}$ and As, two toxic elements exhibiting high volatility, which is in line with wide attention in the literature that is paid to $\mathrm{Hg}[13-15]$ and As $[8,16,17]$. Another two elements are present in all these lists- $\mathrm{Pb}$ and $\mathrm{Cd}$. The behavior of and possibilities of decreasing $\mathrm{Pb}$ emissions were discussed in our previous paper [18]; therefore, this review paper is focused on $\mathrm{Cd}$, due to the unfavorable combination of its high toxicity and volatile character hindering its quantitative retention.

Owing to the increasing amount of industrial, agricultural, forest and domestic wastes, there is a trend toward co-combustion of coal with these waste materials. For example, the amount of municipal solid waste (MSW) of the cities (in world-wide scale) may reach 2.2 billion tonnes per year 
by $2025[19,20]$. Moreover, if an effective and efficient solid waste management is not applied, it can result in health hazards or negative impact on the environment [21]. Therefore, possible interactions of various wastes with coal during co-combustion is discussed herein as well.

The objective of this review paper is to address all important aspects relating to $\mathrm{Cd}$ behavior and interactions during combustion (incineration) processes with particular attention paid on decreasing its emissions.

\section{Cd (and Cl) in Coal}

\subsection{Concentrations of $C d$}

Clarke values for $\mathrm{Cd}$ concentrations in low-rank and high-rank coals are 0.24 and $0.20 \mathrm{ppm}$, which is ca. one- or two-orders of magnitude lower than those of $\mathrm{Pb}$ and $\mathrm{Cr}$ [22]. Since $\mathrm{Cd}$ concentrations in coal are rather variable, Biswas and $\mathrm{Wu}$ [23] provided typical $\mathrm{Cd}$ concentrations range in coal (entering combustors) being $0.033-0.64 \mathrm{ppm}$. For the comparison, Table 1 provides also Cd levels in other related materials, such as in municipal solid waste (ash) [24] or some coal combustion additives (limestone or urea) [25]. It can be deduced from these data that if some of these materials are co-combusted with coal (e.g., in fluidized-bed power stations) the amount of $\mathrm{Cd}$ introduced into the combustion chamber with a waste might be significantly higher than its input mass in coal. In contrast, if limestone (ca. $0.01 \mathrm{ppm} \mathrm{Cd}$ ) or urea (ca. $0.03 \mathrm{ppm} \mathrm{Cd)} \mathrm{[25]} \mathrm{are} \mathrm{put} \mathrm{into} \mathrm{the} \mathrm{furnace} \mathrm{due} \mathrm{to} \mathrm{flue} \mathrm{gas} \mathrm{cleaning,}$ their low $\mathrm{Cd}$ concentrations might result in a diluting effect.

Table 1. Cadmium levels in target materials.

\begin{tabular}{ccc}
\hline Material & Cd Concentration (Range) & References \\
\hline Coal & $0.033-0.64 \mathrm{ppm}$ & {$[23]$} \\
Low rank coal (ash) & $0.24(1.1) \mathrm{ppm}$ & {$[22]$} \\
High rank coal (ash) & $0.20(1.2) \mathrm{ppm}$ & {$[22]$} \\
Municipal solid waste & $0-90 \mathrm{ppm}$ & {$[23]$} \\
Municipal solid waste incineration fly ash & $50-450 \mathrm{ppm}$ & {$[24]$} \\
Municipal wastewater sludge & $100 \mathrm{ppm}$ & {$[23]$} \\
Sewage sludge ash & $2.3-94 \mathrm{ppm}$ & {$[24]$} \\
Limestone & $0.01 \mathrm{ppm}$ & {$[25]$} \\
Urea & $0.03 \mathrm{ppm}$ & {$[25]$} \\
\hline
\end{tabular}

\subsection{Associations of $C d$}

The sulfidic (chalcophylic) associations of $\mathrm{Cd}[26,27]$ is even more dominant than that $\mathrm{Pb}$ (ca. $80 \% \mathrm{Cd}$ in low-rank coals and $65 \% \mathrm{Cd}$ in high-rank coals [28]), which relates primarily to $\mathrm{Cd}$ occurrence in sphalerite. There is also some affinity to pyrite (mainly in high rank coals-25\%) and ca. $10 \%$ silicate-associated $\mathrm{Cd}$ in both high-rank and low-rank coals [28]. Organic affinity of $\mathrm{Cd}$ has been observed in Waterberg Coalfield coal [29], Huaibei Coalfield coal [26] or in coal form Upper Silesian Coal basin [30].

During coal combustion, $\mathrm{Cd}$ behaves as one of the most volatile elements, which corresponds well with its dominant sulfidic affinity accompanied by minor occurrence in organic matter or carbonates; according to Finkelman [28], only ca. 10\% of Cd (in average) is firmly bound in (alumino) silicates.

\section{3. $\mathrm{Cl}$ in Coal (and Wastes)}

Due to the abundant and widely-discussed interactions of $\mathrm{Cd}$ with $\mathrm{Cl}$ during combustion, $\mathrm{Cl}$ levels in coal are important as well. Clarke values of estimated $\mathrm{Cl}$ concentrations in brown coals and hard coals (and their ashes) are 120 and 340 ppm (and 770 and 2100 ppm in corresponding ashes) [31,32]. Therefore, even if $\mathrm{Cd}$ concentrations in low-rank and high-rank coals are similar, higher $\mathrm{Cl}$ content in high-rank coals might favor Cd volatilization (release) from these coals. 
Even though organically-bound (covalent bond) $\mathrm{Cl}$ may also be present in coals, its occurrence in inorganic chlorides ( $\mathrm{NaCl}, \mathrm{KCl}$ etc.) is undoubtedly the most abundant; some "semi-organic" $\mathrm{Cl}$ (i.e., anion $\mathrm{Cl}^{-}$sorbed on organic matter from pore water) was observed as well [31,32].

Fluidized-bed combustion technology is spreading quickly around the world [33] which enables to use also low-grade fuels (biomass, wastes, etc.) whose composition and $\mathrm{Cl}$ levels are of fluctuating quality. For example, refuse-derived fuel typically contains PVC (polyvinyl chloride), sewage sludge often contains higher levels of $\mathrm{FeCl}_{3}, \mathrm{NaCl}$ is present in food residues and biomass may contain higher $\mathrm{Cl}$ (and moisture) concentrations [34-36]. All these different $\mathrm{Cl}$ forms exhibit different effects on $\mathrm{Cd}$ volatilities (which will be discussed in Section 5).

\section{Melting/Boiling Points of Cd Compounds}

Based on thermodynamic equilibrium calculations in oxidizing atmosphere (not considering Cd-Si and $\mathrm{Cd}-\mathrm{Al}$ interactions) [37], the most abundant $\mathrm{Cd}$-compounds during coal combustion are $\mathrm{CdO}$, $\mathrm{CdCl}_{2}, \mathrm{CdSO}_{4}$ and $\mathrm{Cd}$. Melting/boiling points of these compounds are crucial for detailed evaluation of $\mathrm{Cd}$ transformations during coal combustion and are listed in Table 2.

Table 2. Melting points (m.p.) and boiling points (b.p.) of Cd and its target compounds.

\begin{tabular}{cccc}
\hline Compound & m.p./b.p. & Temperature & References \\
\hline Metal & $\mathrm{Cd} \mathrm{m.p.}$ & $321^{\circ} \mathrm{C}$ & {$[38,39]$} \\
& $\mathrm{Cd}$ b.p. & $767^{\circ} \mathrm{C}$ & {$[38,39]$} \\
Oxide & $\mathrm{CdO}$ m.p. & $1540{ }^{\circ} \mathrm{C}$ (sublimation) & {$[39]$} \\
& $\mathrm{CdO}$ b.p. & Sublimation at $900^{\circ} \mathrm{C}$ & {$[38]$} \\
Chloride & $\mathrm{CdCl}_{2}$ m.p. & $564^{\circ} \mathrm{C}$ & {$[38-40]$} \\
& $\mathrm{CdCl}_{2}$ b.p. & $960^{\circ} \mathrm{C}$ & {$[38-41]$} \\
Sulfate & $\mathrm{CdSO}_{4}$ m.p. & $1000^{\circ} \mathrm{C}$ & {$[38,40]$} \\
\hline
\end{tabular}

It is noteworthy to mention also the melting points of some the most abundant interacting species that typically occur during coal combustion, e.g., $\mathrm{NaCl}\left(801^{\circ} \mathrm{C}\right)$ [42], $\mathrm{KCl}\left(770{ }^{\circ} \mathrm{C}\right)$ [42], $\mathrm{CaCl}_{2}$ (ca. $\left.800^{\circ} \mathrm{C}\right)[43], \mathrm{CaSO}_{4}\left(1400^{\circ} \mathrm{C}\right)[43]$.

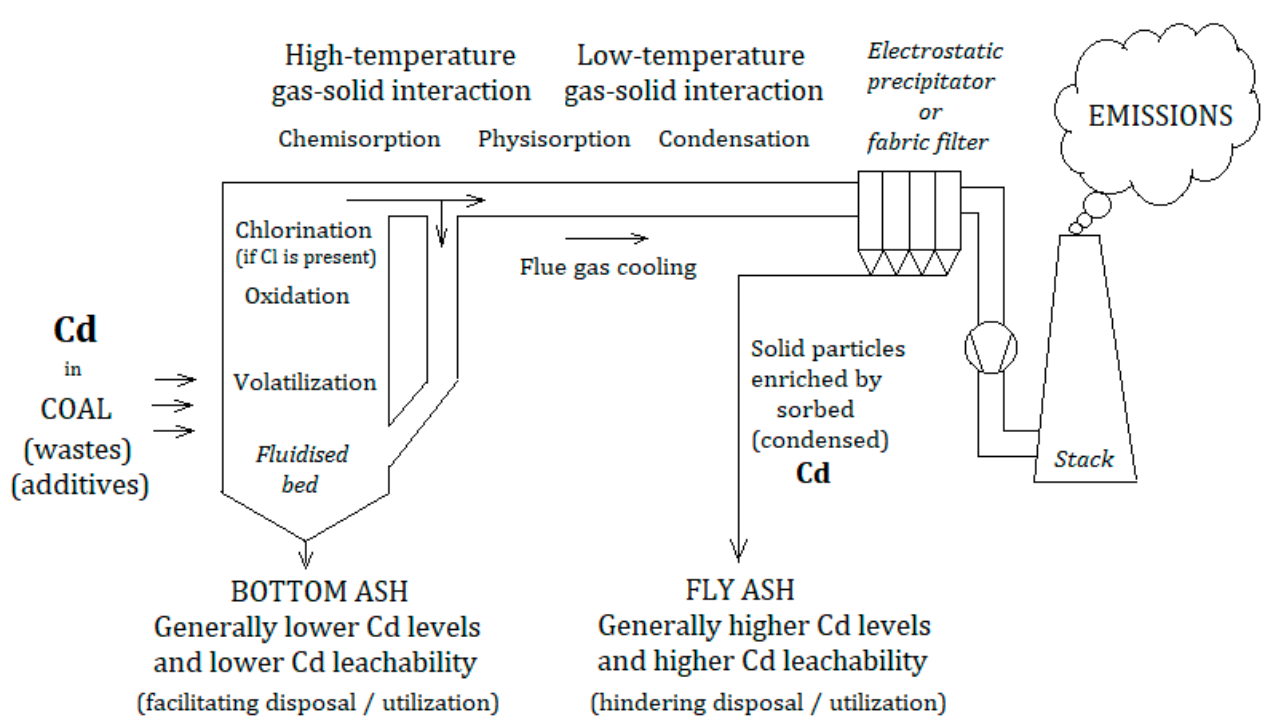

Figure 1. Partitioning of $\mathrm{Cd}$ during coal combustion at fluidised-bed power station.

As melting/boiling points of $\mathrm{CdCl}_{2}$ are lower than those of $\mathrm{CdO}$ or $\mathrm{CdSO}_{4}$, formation of $\mathrm{CdCl}_{2}$ leads to increased volatility of $\mathrm{Cd}$, which is quite hindering to its quantitative capture (which will be discussed in detail in Section 5). The fraction of $\mathrm{Cd}$ that does not condense during flue gas cooling or is 
not retained by additives or ash particles might remain in gaseous form that can easily pass through particulate control device (electrostatic precipitator or fabric filter) as depicted in Figure 1.

\section{Combustion/Retention Experiments without Extra $\mathrm{Cl}$ Added}

\subsection{In-Furnace Adsorbents}

Various adsorbents were tested for $\mathrm{Cd}$ retention in combustion/incineration processes (bauxite, kaolinite, $\mathrm{Al}_{2} \mathrm{O}_{3}$, silica sand, apatite, zeolite, mullite, scallop etc.) Nevertheless, as efficient $\mathrm{Cd}$ retention is a complex phenomenon (depending at least on the temperature, dwell time, atmosphere and concentrations of interacting species) [44], results observed in individual combustion/retention experiments are quite variable, which is shown in Table 3. For example, bauxite is a promising adsorbent of Cd. Nevertheless, in different studies [45-49] the retained fraction of $\mathrm{Cd}$ is rather fluctuating-from $7-14 \%[46,48,49]$ up to $68-74 \%[45,47]$ despite the combustion temperature was similar $\left(700-800{ }^{\circ} \mathrm{C}\right)$, which can be attributed to different composition of the feed and different experimental conditions (including time factor). Similar results are documented also for kaolin(ite) that is widely used for $\mathrm{Cd}$ retention as well [45,46,48-51] —herein, the retention efficiency ranges from $4 \%$ [46] up to $44 \%$ [48,49].

Table 3. Effect of adsorbents on Cd retention.

\begin{tabular}{|c|c|c|c|c|}
\hline Experiment & Evaluated & Adsorbent & Results & References \\
\hline $\begin{array}{l}\mathrm{CdCl}_{2} \text {, thermogravimetric reactor, } \\
\qquad 800{ }^{\circ} \mathrm{C}\end{array}$ & Metal adsorbed & $\begin{array}{c}\text { Bauxite } \\
\text { Alumina } \\
\text { Limestone } \\
\text { Emathlite } \\
\text { Kaolinite } \\
\text { Silica }\end{array}$ & $\begin{array}{l}74 \% \text { * } \\
55 \% \text { * } \\
23 \% \text { * } \\
12 \% \text { * } \\
11 \% \text { * } \\
4 \% \text { * }\end{array}$ & {$[45]$} \\
\hline $\begin{array}{l}\text { Synthetic solid waste (with } \\
\text { Cd-nitrate), fluidized bed } \\
\text { incinerator, } 700^{\circ} \mathrm{C}\left(900^{\circ} \mathrm{C}\right)\end{array}$ & $\begin{array}{l}\text { Cd adsorption } \\
\text { efficiency }\end{array}$ & $\begin{array}{c}\mathrm{Al}_{2} \mathrm{O}_{3} \\
\text { Bauxite } \\
\text { Kaolinite }\end{array}$ & $\begin{array}{l}9 \%(4 \%) * \\
14 \%(9 \%) * \\
5 \%(5 \%) *\end{array}$ & [46] \\
\hline $\begin{array}{c}\text { Wood }+ \text { Cd-acetate, fluidized-bed } \\
\text { incinerator, } 750^{\circ} \mathrm{C}\end{array}$ & Percent capture & $\begin{array}{c}\text { Bauxite } \\
\text { Zeolite } \\
\text { Lime } \\
\text { Sorbent mixture }\end{array}$ & $\begin{array}{l}68 \% \text { * } \\
50 \% \text { * } \\
40 \% \text { * } \\
75 \% \text { * }\end{array}$ & {$[47]$} \\
\hline $\begin{array}{l}\text { Dried sewage sludge }+5 \% \\
\text { adsorbent, drop-tube furnace, } \\
800^{\circ} \mathrm{C}\end{array}$ & Captured fraction & $\begin{array}{l}\text { Kaolin } \\
\text { Zeolite } \\
\text { Limestone } \\
\text { Scallop } \\
\text { Mullite } \\
\text { Apatite } \\
\text { Bauxite } \\
\text { Silica } \\
\text { Alumina }\end{array}$ & $\begin{array}{l}44 \% \text { * } \\
27 \% \text { * } \\
22 \% \text { * } \\
19 \% \text { * } \\
15 \% \text { * } \\
14 \% \text { * } \\
7 \% \text { * } \\
4 \% \text { * } \\
2 \% \text { * }\end{array}$ & {$[48,49]$} \\
\hline $\begin{array}{c}\text { Coal }+ \text { kaolinite, electrically heated } \\
\text { combustor }\end{array}$ & $\begin{array}{l}\text { Relative } \\
\text { enrichment factor }\end{array}$ & $\begin{array}{l}1100^{\circ} \mathrm{C} \\
1200^{\circ} \mathrm{C} \\
1300^{\circ} \mathrm{C}\end{array}$ & $\begin{array}{l}0.4^{*} \\
2.1^{*} \\
0.75^{*}\end{array}$ & {$[50]$} \\
\hline $\begin{array}{l}\text { Coal }+ \text { kaolinite, electrically heated } \\
\text { combustor, } 1100^{\circ} \mathrm{C}\end{array}$ & Concentration & $\begin{array}{l}\text { Kaolinite } \\
\text { Bauxite } \\
\mathrm{CaO}\end{array}$ & $\begin{array}{l}0.38 \mathrm{ppm}^{*} \\
0.40 \mathrm{ppm}^{*} \\
0.39 \mathrm{ppm}^{*}\end{array}$ & {$[50]$} \\
\hline $\begin{array}{c}\text { Sewage sludge + additive (5:1), } \\
\text { thermogravimetric analyzer, } \\
1200{ }^{\circ} \mathrm{C}\end{array}$ & Fixed ratio of $\mathrm{Cd}$ & $\begin{array}{c}\text { No additive } \\
\mathrm{CaO} \\
\text { Kaolin }\end{array}$ & $\begin{array}{l}25 \% \text { * } \\
20 \% \text { * } \\
22 \% \text { * }\end{array}$ & {$[51]$} \\
\hline $\begin{array}{c}\text { Coal }+\mathrm{CaCO}_{3} \text { modified by } \\
3 \text { different additives, muffle furnace, } \\
900{ }^{\circ} \mathrm{C}\end{array}$ & Cd-capturing rate & $\begin{array}{c}\mathrm{Na}_{2} \mathrm{CO}_{3} \\
\mathrm{~K}_{2} \mathrm{CO}_{3} \\
\mathrm{Al}_{2}\left(\mathrm{SO}_{4}\right)_{3}\end{array}$ & $\begin{array}{l}22.83 \% \\
57.37 \% \\
47.55 \%\end{array}$ & {$[52]$} \\
\hline $\begin{array}{l}\text { Fluidized-bed incinerator, artificial } \\
\text { solid waste (with Cd-nitrate), } 900{ }^{\circ} \mathrm{C}\end{array}$ & $\begin{array}{l}\text { \% retention } \\
\text { (on silica sand) }\end{array}$ & $\begin{array}{c}\text { no } \mathrm{Na} \text { added } \\
1.2 \% \mathrm{Na} \text { added }\end{array}$ & $\begin{array}{l}5 \% * \\
46 \% *\end{array}$ & {$[53]$} \\
\hline
\end{tabular}

* Rough estimation (data from diagram). 


\subsubsection{Bauxite}

An effective retention of $\mathrm{Cd}$ can be achieved by bauxite [45-47], mostly at lower temperatures $\left(700-800^{\circ} \mathrm{C}\right)[45,47]$. However, at higher temperatures $\left(1100^{\circ} \mathrm{C}\right)$ the ability of bauxite to retain $\mathrm{Cd}$ was observed as well [50] - in this experiment, adsorbent pre-mixed with coal was combusted in a vertical tube reactor at $1100{ }^{\circ} \mathrm{C}$ and bauxite provided better retention results than kaolinite and $\mathrm{CaO}$ (based on evaluation of particles with medium size). At lower temperatures $\left(700\right.$ or $\left.900{ }^{\circ} \mathrm{C}\right)$, during synthetic MSW incineration bauxite was better adsorbent of $\mathrm{Cd}$ than kaolinite and $\mathrm{Al}_{2} \mathrm{O}_{3}$ [46], which might indicate that the admixture of other minerals/components in bauxite might favor $\mathrm{Cd}$ retention in comparison with pure $\mathrm{Al}_{2} \mathrm{O}_{3}$. Moreover, $\left(\mathrm{at} 700{ }^{\circ} \mathrm{C}\right.$ ) bauxite was the best adsorbent not only for $\mathrm{Cd}$ but also for $\mathrm{Cr}, \mathrm{Pb}$ and $\mathrm{Cu}$. Interaction of $\mathrm{CdO}$ and $\mathrm{CdCl}_{2}$ with $\mathrm{Al}_{2} \mathrm{O}_{3}$ can be described by Reactions (1) [47] and (2) [45,47].

$$
\begin{gathered}
\mathrm{CdO}+\mathrm{Al}_{2} \mathrm{O}_{3} \rightarrow \mathrm{CdAl}_{2} \mathrm{O}_{4}(\mathrm{~s}) \\
\mathrm{CdCl}_{2}+\mathrm{Al}_{2} \mathrm{O}_{3}+\mathrm{H}_{2} \mathrm{O} \rightarrow \mathrm{CdO} \cdot \mathrm{Al}_{2} \mathrm{O}_{3}(\mathrm{~s})+2 \mathrm{HCl}(\mathrm{g})
\end{gathered}
$$

\subsubsection{Kaolinite}

Yao and Naruse $[48,49]$ tested 9 adsorbents for in-furnace retention of Cd during dried sewage sludge combustion in drop-tube furnace at $800{ }^{\circ} \mathrm{C}$. The most efficient $\mathrm{Cd}$ capture was observed in the case of kaolinite $\left(31.55 \mathrm{~m}^{2} / \mathrm{g}\right)$, followed by zeolite $\left(21.40 \mathrm{~m}^{2} / \mathrm{g}\right)$, limestone $\left(1.87 \mathrm{~m}^{2} / \mathrm{g}\right)$, scallop $\left(0.85 \mathrm{~m}^{2} / \mathrm{g}\right)$, apatite $\left(35.14 \mathrm{~m}^{2} / \mathrm{g}\right) \sim$ mullite $\left(8.60 \mathrm{~m}^{2} / \mathrm{g}\right)$, bauxite $\left(0.92 \mathrm{~m}^{2} / \mathrm{g}\right)$, silica $\left(1.29 \mathrm{~m}^{2} / \mathrm{g}\right)$ and alumina $\left(1.23 \mathrm{~m}^{2} / \mathrm{g}\right)$ - captured fractions of $\mathrm{Cd}$ are given in Table 3 . The results indicate that specific surface area is not the only affecting factor. Efficient retention by kaolinite can be described by Reaction (3) $[48,49]$ and is in line with the conclusion that the retained $\mathrm{Cd}$ in residual ash may be in the form of binary oxides $\mathrm{CdO} \cdot \mathrm{Al}_{2} \mathrm{O}_{3}$ or $\mathrm{CdO} \cdot \mathrm{SiO}_{2}$ [25].

$$
\mathrm{CdCl}_{2}+\operatorname{kaolin}\left(\mathrm{Al}_{2} \mathrm{O}_{3} \cdot 2 \mathrm{SiO}_{2} \cdot 2 \mathrm{H}_{2} \mathrm{O}\right) \rightarrow \mathrm{CdO} \cdot \mathrm{Al}_{2} \mathrm{O}_{3} \cdot 2 \mathrm{SiO}_{2}+2 \mathrm{HCl}
$$

Kaolinite was also tested during high-temperature combustion. Chen et al. [51] presented better retention of $\mathrm{Cd}$ on kaolin than on $\mathrm{CaO}$ if added to sludge prior to combustion at $1200{ }^{\circ} \mathrm{C}$ (in TGA); however, it is interesting that absolutely the best retention results were observed if no adsorbent was added to the sludge (as shown in Table 3).

Wendt and Lee [54] document efficient retention of $\mathrm{Cd}(\mathrm{and} \mathrm{Pb})$ using blended adsorbent containing kaolinite and calcite (with admixture of lime) injected into flame in vertical combustor at 1160 and $1280^{\circ} \mathrm{C}$; the former temperature was better for the retention of $\mathrm{Pb}$, the latter was advantageous for the capture of $\mathrm{Cd}$ (if there was no $\mathrm{Pb}$ ). If both $\mathrm{Cd}$ and $\mathrm{Pb}$ were present, the lower temperature $\left(1160^{\circ} \mathrm{C}\right)$ was good also for the retention of $\mathrm{Cd}$, which was interpreted by surface melt formed on the adsorbent particles due to the enhancing effect of $\mathrm{Pb}$.

\subsubsection{Silica Sand}

Silica sand can also adsorb heavy metals (HMs) including Cd [55,56]. However, in both studies, the retention of $\mathrm{Cd}$ was somewhat worse than that of $\mathrm{Pb}$ and can be described by Reaction (4) [47]

$$
\mathrm{CdO}+\mathrm{SiO}_{2} \rightarrow \mathrm{CdSiO}_{3}(\mathrm{~s})
$$

The effect of $\mathrm{Na}$ (if $\mathrm{NaNO}_{3}$ was added to silica sand) on the retention of $\mathrm{Cd}$ and $\mathrm{Pb}$ was studied by Kuo et al. [53]. The presence of $\mathrm{Na}$ increased the retention ability of silica sand at $700-900{ }^{\circ} \mathrm{C}$; at $900{ }^{\circ} \mathrm{C}$ the increase was the most significant-from ca. $5 \%$ retained $\mathrm{Cd}$ (no Na) up to ca. $46 \%$ (for $1.2 \% \mathrm{Na}$ ). If $\mathrm{Na}$ was added at 800 and $900{ }^{\circ} \mathrm{C}$, the retention of $\mathrm{Cd}$ was even better than that of $\mathrm{Pb}$ (ca. $41 \% \mathrm{~Pb}$ vs. $46 \% \mathrm{Cd}$ at $900^{\circ} \mathrm{C}$ ). The observation was attributed to the formation of low-melting-point eutectics on the adsorbent particle surfaces; the effect of physical co-condensation was presumed as being also possible. 


\subsubsection{Calcareous Adsorbents}

Calcareous adsorbents were tested for the retention of $\mathrm{Cd}$ as well. In general, if no extra $\mathrm{Cl}$ (or S) was added to the feed, then bauxite, kaolinite or zeolite typically provide more efficient retention (than calcareous adsorbents). However, in the case of higher $\mathrm{Cl}$ (or S) levels in the feed, calcareous adsorbents $\left(\mathrm{CaCO}_{3}\right.$ or $\left.\mathrm{CaO}\right)$ provided usually better results, which will be discussed in detail in Section 5.2.1.

\subsection{Other Approaches}

Instead of adding kaolin directly into the furnace, suspension of water with kaolinite can be used also in semi-dry spray tower at $150-170{ }^{\circ} \mathrm{C}$ [57]. Synthetic solid waste was combusted at $800{ }^{\circ} \mathrm{C}$ and in semi-dry spray tower limestone, kaolinite, $\mathrm{Al}_{2} \mathrm{O}_{3}$ or no sorbent (i.e., only water) were applied. For the retention of $\mathrm{Cd}$, the best results were achieved by spraying with water without any adsorbent, while in the case of other HMs, added adsorbents provided better results than water.

Peng et al. [55] reported promising Cd-retention results by means of low-temperature two-stage fluidized bed incinerator where artificial MSW was combusted. The temperature at the first stage was 550,650 and $750^{\circ} \mathrm{C}$, at the second (filtration) stage it was always $800^{\circ} \mathrm{C}$. The best $\mathrm{Cd}$ retention was obtained at $550{ }^{\circ} \mathrm{C}$ (at the first stage). Efficient Cd capture in this low-temperature two-stage system was attributed to $\mathrm{Cd}$ vaporization, chemical adsorption and filtration in the second stage, which is in line with conclusions of other studies [58,59]. It is worth mentioning that $\mathrm{Cd}$ retention at $650{ }^{\circ} \mathrm{C}$ (the 1st stage) was lower than that at $550^{\circ} \mathrm{C}$ but almost all this decrease was retained later during the filtration at the 2nd stage. Then, the overall retention of $\mathrm{Cd}$ at $650^{\circ} \mathrm{C}$ was only slightly lower than that at $550{ }^{\circ} \mathrm{C}$ (due to efficient filtration at the second stage).

\section{Effect of $\mathrm{Cl}$}

In general, the effect of $\mathrm{Cl}$ on behavior of $\mathrm{Cd}$ (and other $\mathrm{HMs}$ ) is studied namely due to shifting CdO-CdCl ${ }_{2}$ equilibrium toward the formation of chloride [60]. As chlorides of most metals (including $\mathrm{Cd}$ ) exhibit higher volatility than oxides, there are two dominant reasons why attention is paid to this phenomenon:

(i) Due to enhanced emissions of $\mathrm{Cd}$ (and other HMs) during combustion/incineration processes (high volatility of $\mathrm{CdCl}_{2}$ favors $\mathrm{Cd}$ occurrence in gaseous form that might easily pass through the air-pollution control device).

(ii) Due to removal of HMs from combustion (incineration) ashes which facilitates their further technological utilization. High volatility of $\mathrm{CdCl}_{2}$ facilitates $\mathrm{Cd}$ release from bottom ash leading to lower $\mathrm{Cd}$ concentrations and better ash utilization perspectives. In contrast, due to volatilization/condensation mechanism, certain fraction of Cd might condense/adsorb on fly ash particles increasing $\mathrm{Cd}$ levels there (Figure 1). Moreover, these fractions often exhibit increased leachability.

Affinity of individual elements to $\mathrm{Cl}$ is different-approximate sequences of these affinities can be found in the literature [61-64]:

$$
\begin{gathered}
\mathrm{Tl}>\mathrm{Cu}>\mathrm{Zn}>\mathrm{Pb}>\mathrm{Co}>\mathrm{Mn}>\mathrm{Sn}>\mathrm{Hg} \\
\mathrm{Cu}>\mathrm{Tl}>(\mathrm{S} n, \mathrm{Zn})>(\mathrm{Pb}, \mathrm{Cd}, \mathrm{Ni}, \mathrm{Co}, \mathrm{Sb}) \\
\mathrm{H}>\mathrm{Na}>\text { other HMs } \\
H>(\mathrm{Na}, \mathrm{K})>\mathrm{Pb}
\end{gathered}
$$

There is a consensus in the literature that $\mathrm{Cd}$ exhibits lower affinity to $\mathrm{Cl}$ than $\mathrm{Pb}$ [65].

The idea of close partitioning of $\mathrm{Cd}$ and $\mathrm{Cl}$ during coal combustion is supported (i.a.) by strong positive linear relationship between relative enrichment factors of $\mathrm{Cd}$ and $\mathrm{Cl}$ in filter ash and cyclone ash [66]. 
Papers documenting the (typically enhancing) effect of $\mathrm{Cl}$ on $\mathrm{Cd}$ volatility are abundant in the literature-Table 4 provides at least some typical illustrative examples of this effect. As shown in Table 4, various Cl-bearing compounds are able to influence $\mathrm{Cd}$ partitioning, such as $\mathrm{NaCl}, \mathrm{PVC}$, $\mathrm{NH}_{4} \mathrm{Cl}, \mathrm{FeCl}_{3}, \mathrm{CaCl}_{2}$ or $\mathrm{MgCl}_{2}$. Despite some similar features, the effect of individual chlorination agents is different.

There is a consensus in the literature that there are two general chlorination mechanisms-direct and indirect one. Direct chlorination is thought to be a prevalent mechanism in the case of $\mathrm{NaCl}$ where (high-temperature) direct reaction between $\mathrm{NaCl}$ and $\mathrm{Cd}$ (or other $\mathrm{HMs}$ ) oxides occur [67]. Indirect chlorination is more common and was observed (e.g.,) in the case of $\mathrm{PVC}, \mathrm{CaCl}_{2}$ or $\mathrm{MgCl}_{2}$ and is based on (low-temperature) release of chlorination agent $\left(\mathrm{HCl}, \mathrm{Cl}_{2}\right)$ that is followed by its reaction with $\mathrm{CdO}$ (or other HMs oxides) [68].

Table 4. Effect of $\mathrm{Cl}$ compounds on Cd volatility.

\begin{tabular}{|c|c|c|c|c|}
\hline Experiment & Parameter Evaluated & Chlorine Added & Results & References \\
\hline $\begin{array}{l}\text { Bitum. coal + SRF } \\
\quad * \text { ca. } 1200^{\circ} \mathrm{C}\end{array}$ & $\begin{array}{l}\text { Relative enrichment factor in } \\
\text { filter ash vs. cyclone ash } \\
\text { (related to } \mathrm{Al} \text { ) }\end{array}$ & $\begin{array}{c}- \\
1 \text { and } 2 \% \mathrm{NaCl} \\
2 \text { and } 4 \% \mathrm{PVC}\end{array}$ & $\begin{array}{l}5-7 \\
8 \text { and } 10 \\
6 \text { and } 23\end{array}$ & [66] \\
\hline $\begin{array}{l}\text { Bitum. coal + SRF } \\
\quad * \text {, ca. } 1200^{\circ} \mathrm{C}\end{array}$ & $\begin{array}{l}\text { TEM-EDS analysis of filter } \\
\text { ash aerosols from } \\
\text { vaporization mode }\end{array}$ & $\begin{array}{c}- \\
1 \% \mathrm{NaCl} \\
2 \% \mathrm{PVC}\end{array}$ & $\begin{array}{c}<0.5 \% \mathrm{Cd} /<0.5 \% \mathrm{Cl} \\
1.5 \% \mathrm{Cd} / 6 \% \mathrm{Cl} \\
1 \% \mathrm{Cd} / 1.5 \% \mathrm{Cl}\end{array}$ & [66] \\
\hline Solid waste, $900^{\circ} \mathrm{C}$ & Volatilized fraction of $\mathrm{Cd}$ & $\begin{array}{c}- \\
1 \text { and } 3 \% \mathrm{Cl}(\mathrm{NaCl}) \\
1 \text { and } 3 \% \mathrm{Cl}(\mathrm{PVC})\end{array}$ & $\begin{array}{c}47 \% \\
85 \text { and } 90 \% \\
90 \text { and } 95 \% \\
\end{array}$ & [68] \\
\hline $\begin{array}{l}\text { Wastewater sludge, } \\
850^{\circ} \mathrm{C}\end{array}$ & Volatilization rate & $\begin{array}{c}\mathrm{No} \mathrm{NH}_{4} \mathrm{Cl}(0.1 \% \mathrm{Cl}) \\
\text { With } \mathrm{NH}_{4} \mathrm{Cl}(0.5 \% \\
\mathrm{Cl})\end{array}$ & $\begin{array}{l}40 \% \\
85 \%\end{array}$ & [69] \\
\hline $\begin{array}{l}\text { Simulated MSW, } \\
800{ }^{\circ} \mathrm{C}\end{array}$ & $\begin{array}{l}\text { Percentage in fly ash and } \\
\text { flue gas }\end{array}$ & $\begin{array}{r}\text { No } \mathrm{FeCl}_{3} \\
\text { With } \mathrm{FeCl}_{3}\end{array}$ & $\begin{array}{l}20 \% \text { in fly ash ***, } \\
80 \% \text { in flue gas *** } \\
80 \% \text { in fly ash ***, } \\
20 \% \text { in flue gas *** }\end{array}$ & [70] \\
\hline $\begin{array}{l}\text { MSW fly ash, } \\
800^{\circ} \mathrm{C}\end{array}$ & $\begin{array}{l}\text { Removal percentage of } \mathrm{Cd} \\
\text { from fly ash }\end{array}$ & $\begin{array}{c}- \\
100 \mathrm{~g} / \mathrm{kg} \mathrm{Cl}(\mathrm{NaCl}) \\
100 \mathrm{~g} / \mathrm{kg} \mathrm{Cl}\left(\mathrm{MgCl}_{2}\right) \\
100 \mathrm{~g} / \mathrm{kg} \mathrm{Cl}\left(\mathrm{CaCl}_{2}\right)\end{array}$ & $\begin{array}{l}50 \%{ }^{* * *} \\
48 \% * * * \\
90 \% * * * \\
76 \% * * *\end{array}$ & [71] \\
\hline
\end{tabular}

* Solid recovered fuel; ${ }^{* *}$ Percentage in bottom ash was within a few \% (neglected); ${ }^{* * *}$ Rough estimation (from diagram).

\subsection{Direct Chlorination (Effect of $\mathrm{NaCl}$ )}

Direct chlorination mechanism of Cd (and other HMs) is typically discussed in the case of $\mathrm{NaCl}$ [71], which is present in coals, MSW (food residues), sludges, calcareous additives etc.

During simulated MSW incineration in horizontal tube furnace $\left(900^{\circ} \mathrm{C}, 60 \mathrm{~min}\right), \mathrm{NaCl}$ did not lowered volatilization temperature of $\mathrm{Cd}$ (it remains within the range $600{ }^{\circ} \mathrm{C}-700{ }^{\circ} \mathrm{C}$ ) but $\mathrm{NaCl}$ enhanced the volatilization rates at $700{ }^{\circ} \mathrm{C}-900{ }^{\circ} \mathrm{C}$ [68]. Enhanced $\mathrm{Cd}$ volatilization initiated at $700{ }^{\circ} \mathrm{C}-800{ }^{\circ} \mathrm{C}$, which is lower than the temperature of $\mathrm{HCl}$ release from $\mathrm{NaCl}\left(\mathrm{t}>900{ }^{\circ} \mathrm{C}\right)$; therefore, the indirect chlorination mechanism is less probable in this case [68].

Based on thermodynamic calculations, it was concluded that both $\mathrm{SiO}_{2}$ and $\mathrm{Al}_{2} \mathrm{O}_{3}$ are needed for direct chlorination via $\mathrm{NaCl}$ (Reaction (5)) [68]:

$$
2 \mathrm{NaCl}+\mathrm{CdO}+2 \mathrm{SiO}_{2}(c)+\mathrm{Al}_{2} \mathrm{O}_{3}(c) \rightarrow \mathrm{CdCl}_{2}(g)+2 \mathrm{NaAlSiO}_{4}(c)
$$

According to Nowak et al. [71] and Chan et al. [41], reaction of $\mathrm{NaCl}$ with $\mathrm{H}_{2} \mathrm{O}$ and $\mathrm{O}_{2}$ (releasing $\mathrm{HCl}$ and $\mathrm{Cl}_{2}$ ) is less probable than evaporation of $\mathrm{NaCl}$ without reacting. However, in the case of direct 
chlorination, $\mathrm{NaCl}$ evaporation or melting is favorable because the mixture of $\mathrm{Cl}$ and $\mathrm{Cd}$ (or other $\mathrm{HM}$ ) is not typically homogeneous.

This is consistent with the conclusion of Yu et al. [42]: when temperature reaches melting point of $\mathrm{NaCl}\left(801^{\circ} \mathrm{C}\right)$ or $\mathrm{KCl}\left(770{ }^{\circ} \mathrm{C}\right), \mathrm{NaCl}$ or $\mathrm{KCl}$ become liquid phase; then, the reaction rates between liquid $\mathrm{NaCl} / \mathrm{KCl}$ and $\mathrm{SiO}_{2}$ or $\mathrm{Al}_{2} \mathrm{O}_{3}$ can be accelerated. At higher temperatures, $\mathrm{NaCl}$ or $\mathrm{KCl}$ was further vaporized into gas phase and the formation of $\mathrm{HCl}$ or $\mathrm{Cl}_{2}$ through gas-solid reaction can occur (as described in Reactions (2)-(6)) [42,67]:

$$
\begin{gathered}
2 \mathrm{NaCl}+\mathrm{SiO}_{2}+\mathrm{O}_{2} \rightarrow \mathrm{Na}_{2} \mathrm{O} \cdot \mathrm{SiO}_{2}+\mathrm{Cl}_{2} \\
2 \mathrm{NaCl}+\mathrm{SiO}_{2}+\mathrm{H}_{2} \mathrm{O} \rightarrow \mathrm{Na}_{2} \mathrm{O} \cdot \mathrm{SiO}_{2}+2 \mathrm{HCl} \\
2 \mathrm{NaCl}+2 \mathrm{SiO}_{2}+\mathrm{Al}_{2} \mathrm{O}_{3}+\mathrm{H}_{2} \mathrm{O} \rightarrow 2 \mathrm{NaAlSiO}_{4}+2 \mathrm{HCl} \\
2 \mathrm{NaCl}+6 \mathrm{SiO}_{2}+\mathrm{Al}_{2} \mathrm{O}_{3}+\mathrm{H}_{2} \mathrm{O} \rightarrow 2 \mathrm{NaAlSi}_{3} \mathrm{O}_{8}+2 \mathrm{HCl} \\
2 \mathrm{NaCl}+2 \mathrm{SiO}_{2}+\mathrm{H}_{2} \mathrm{O} \rightarrow \mathrm{Na}_{2} \mathrm{Si}_{2} \mathrm{O}_{5}+2 \mathrm{HCl}
\end{gathered}
$$

In contrast, $\mathrm{CaCl}_{2}$ or $\mathrm{MgCl}_{2}$ directly react with $\mathrm{H}_{2} \mathrm{O}$ and/or $\mathrm{O}_{2}$ releasing $\mathrm{HCl}$ and/or $\mathrm{Cl}_{2}$ (i.e., $\mathrm{Al}_{2} \mathrm{O}_{3}$ or $\mathrm{SiO}_{2}$ are not needed for this release) and are thought to be more efficient chlorination agents.

However, it should be mentioned in this context that when MSW incineration fly ash was roasted in the rotary reactor at $1000{ }^{\circ} \mathrm{C}(60 \mathrm{~min})$, added $\mathrm{NaCl}$ even slightly lowered the $\mathrm{Cd}$ removal [71]. The authors hypothesized that $\mathrm{NaCl}$ could probably form azeotropes (vapor pressure minima) with HM chlorides.

The results are opposite to those of Wang et al. [68] (where $\mathrm{NaCl}$ enhanced $\mathrm{Cd}$ volatilization at $\left.700{ }^{\circ} \mathrm{C}-900^{\circ} \mathrm{C}\right)$; probably due to higher temperature $\left(1000^{\circ} \mathrm{C}\right)$ used in the study of Nowak et al. [71] where $\mathrm{NaCl}$ might favor surface melt on the particles which supports $\mathrm{Cd}$ retention and thereby hinders Cd evaporation.

\subsection{Indirect Chlorination}

Indirect chlorination is more common than direct mechanism and is based on release of $\mathrm{HCl}$ or $\mathrm{Cl}_{2}$ from $\mathrm{Cl}$-donator followed by interaction of $\mathrm{Cl}$-containing species $\left(\mathrm{HCl}, \mathrm{Cl}_{2}\right)$ with $\mathrm{CdO}$ (or other HM oxides) typically increasing its volatility.

Step 1 is the formation of $\mathrm{HCl} / \mathrm{Cl}_{2}$ by interaction with $\mathrm{O}_{2} / \mathrm{H}_{2} \mathrm{O}[24,32,42]$ (Reactions (7)-(9)):

$$
\begin{gathered}
\mathrm{MgCl}_{2}\left(\text { or } \mathrm{CaCl}_{2}\right)+\frac{1}{2} \mathrm{O}_{2} \rightarrow \mathrm{MgO}(\text { or } \mathrm{CaO})+\mathrm{Cl}_{2} \\
\mathrm{MgCl}_{2}\left(\text { or } \mathrm{CaCl}_{2}\right)+\mathrm{H}_{2} \mathrm{O} \rightarrow \mathrm{MgO}(\text { or } \mathrm{CaO})+2 \mathrm{HCl} \\
\mathrm{Cl}_{2}+\mathrm{H}_{2} \mathrm{O} \rightarrow 2 \mathrm{HCl}+\frac{1}{2} \mathrm{O}_{2}
\end{gathered}
$$

Interactions with (alumino)silicates are given [24] by Reactions (10)-(13):

$$
\begin{aligned}
& \mathrm{CaCl}_{2}(\mathrm{l})+\mathrm{H}_{2} \mathrm{O}(\mathrm{g})+\mathrm{SiO}_{2}(\mathrm{~s}) \rightarrow \mathrm{CaSiO}_{3}(\mathrm{~s})+2 \mathrm{HCl}(\mathrm{g}) \\
& \mathrm{CaCl}_{2}(\mathrm{l})+\frac{1}{2} \mathrm{O}_{2}(\mathrm{~g})+\mathrm{SiO}_{2}(\mathrm{~s}) \rightarrow \mathrm{CaSiO}_{3}(\mathrm{~s})+\mathrm{Cl}_{2}(\mathrm{~g}) \\
& \mathrm{CaCl}_{2}(\mathrm{l})+\mathrm{H}_{2} \mathrm{O}(\mathrm{g})+\mathrm{Al}_{2} \mathrm{O}_{3}(\mathrm{~s}) \rightarrow \mathrm{CaAl}_{2} \mathrm{O}_{4}(\mathrm{~s})+2 \mathrm{HCl}(\mathrm{g}) \\
& \mathrm{CaCl}_{2}(\mathrm{l})+\frac{1}{2} \mathrm{O}_{2}(\mathrm{~g})+\mathrm{Al}_{2} \mathrm{O}_{3}(\mathrm{~s}) \rightarrow \mathrm{CaAl}_{2} \mathrm{O}_{4}(\mathrm{~s})+\mathrm{Cl}_{2}(g)
\end{aligned}
$$

Step 2 is chlorination of $\mathrm{CdO}$ (in oxidizing atmosphere) [72] (Reaction (14)):

$$
\mathrm{CdO}(s)+2 \mathrm{HX}(g) \rightarrow \mathrm{CdX}_{2}(g)+\mathrm{H}_{2} \mathrm{O}(g)
$$


where $\mathrm{X}=\mathrm{Cl}, \mathrm{Br}, \mathrm{F}, \mathrm{I}$.

Since $\mathrm{Cl}$ levels are typically higher than those of $\mathrm{Br}, \mathrm{F}$ and I, interactions of $\mathrm{CdO}$ and $\mathrm{HCl}$ are expected to be more abundant than those with $\mathrm{HBr}$, HF and HI.

Individual chlorination agents exhibit different tendency to release $\mathrm{Cl}$, which can be quantified by equilibrium partial pressures over these chlorination agents; equilibrium partial pressures increase in the sequence [41]:

$$
\mathrm{NaCl}>\mathrm{CaCl}_{2}>\mathrm{FeCl}_{2}>\mathrm{MgCl}_{2}>\mathrm{AlCl}_{3}\left(600-1200{ }^{\circ} \mathrm{C}\right)
$$

$\mathrm{Cd}$ removal during muffle-furnace incineration tests with MSW incineration ashes was evaluated after addition of $\mathrm{NaCl}, \mathrm{MgCl}_{2}$ and $\mathrm{CaCl}_{2}$ in the temperature range of $800{ }^{\circ} \mathrm{C}-1200{ }^{\circ} \mathrm{C}$ [71]. Due to the naturally high volatility of $\mathrm{Cd}$, the experiments at $900-1200{ }^{\circ} \mathrm{C}$ were quite inconclusive for all chlorination agents as all removal efficiencies (volatilities) were nearly $100 \%$. Nevertheless, at $800{ }^{\circ} \mathrm{C}$, only increasing amount of $\mathrm{MgCl}_{2}$ and $\mathrm{CaCl}_{2}$ enhanced original Cd volatility (50\%) up to ca. $90 \%$ in the case of $\mathrm{MgCl}_{2}(100-150 \mathrm{~g} \mathrm{Cl} / \mathrm{kg})$ or up to ca. $85 \%$ in the case of $\mathrm{CaCl}_{2}(150-200 \mathrm{~g} \mathrm{Cl} / \mathrm{kg})$. As these experiments were conducted with the aim to remove $\mathrm{Cd}$ (and other HMs) from the ash, roasting time was set as $20 \mathrm{~h}$. Therefore, application of these results for the estimation of the volatility of $\mathrm{Cd}$ during e.g., fluidized-bed combustion (FBC) at $850{ }^{\circ} \mathrm{C}$ can be quite misleading as dwell time in high-temperature zone in fluidized bed is significantly shorter.

These results are consistent with very high volatility of $\mathrm{Cd}$ at $1000^{\circ} \mathrm{C}(60 \mathrm{~min})$ when addition of $\mathrm{NaCl}, \mathrm{AlCl}_{3}, \mathrm{MgCl}_{2}, \mathrm{FeCl}_{3}$ and $\mathrm{CaCl}_{2}$ were tested. Without these agents, the $\mathrm{Cd}$ removal exceeded $80 \%$ and if $0.3 \mathrm{~g} \mathrm{Cl}$ was added (by aforementioned agents) the removal reached ca. $95 \%$ and was comparable for all these chlorination agents [41]. Nevertheless, also in this case, 60 min roasting time is still too long to be used also for the evaluation of $\mathrm{Cd}$ volatility at power station (these experiments were conducted with the aim to remove HMs from the ash).

Indirect chlorination mechanism was considered as the most probable underlying mechanism of $\mathrm{MgCl}_{2}$ [71]; in the case of $\mathrm{CaCl}_{2}$ it prevails as well (even if direct chlorination might also occur [71]).

\subsubsection{Indirect Chlorination by PVC and Interactions with Calcareous Minerals}

A typical example of an indirect chlorination agent is PVC releasing $\mathrm{HCl}$ at ca. $240{ }^{\circ} \mathrm{C}$ (in oxidizing atmosphere) $[68,73,74]$, which corresponds with low-temperature volatilization.

During incineration experiments with simulated MSW [68], PVC lowered initial volatilization temperature from $600-700{ }^{\circ} \mathrm{C}$ to ca. $500{ }^{\circ} \mathrm{C}$ (which is initial volatilization temperature of $\mathrm{CdCl}_{2}$ ). At higher temperatures $\left(\mathrm{t}>600^{\circ} \mathrm{C}\right.$ ) it enhanced the vaporization rates (in contrast to $\mathrm{NaCl}$ that did not lower volatilization temperature). In the presence of $\mathrm{PVC}$ in the feed waste, $\mathrm{Cd}$ reached a maximum volatilization rate at $600-700{ }^{\circ} \mathrm{C}$, which is lower than in the case of $\mathrm{Pb}\left(800{ }^{\circ} \mathrm{C}-900{ }^{\circ} \mathrm{C}\right)$.

$\mathrm{HCl}$ released from PVC (or other indirect chlorination agents) enhances the volatility of $\mathrm{Cd}$ and other HMs, unless it is retained by ash components, e.g., by calcareous additives used during FBC [75-77].

There is a consensus in the literature that $\mathrm{CaO}$ can adsorb $\mathrm{HCl}(\mathrm{g})$ forming $\mathrm{CaCl}_{2}$ with optimal temperature range of ca. $500{ }^{\circ} \mathrm{C}-650^{\circ} \mathrm{C}$. However, at higher temperatures (than ca. $700{ }^{\circ} \mathrm{C}$ ) the retained $\mathrm{Cl}$ is released back which is then available for the chlorination of $\mathrm{Cd}$ and other HMs again $[68,76,77]$. Interaction with $\mathrm{CaCO}_{3}$ has also been described in the literature [43] with optimal temperature range of $600-850^{\circ} \mathrm{C}$ (Reaction (15)):

$$
\mathrm{CaCO}_{3}+2 \mathrm{HCl} \rightarrow \mathrm{CaCl}_{2}+\mathrm{CO}_{2}+\mathrm{H}_{2} \mathrm{O}
$$

This is consistent with observations of Tang et al. [78] adding $\mathrm{CaO}$ or $\mathrm{CaCO}_{3}$ to $\mathrm{MSW}$ and evaluating $\mathrm{Cd}$ retention in bottom ash. At $700{ }^{\circ} \mathrm{C}-800{ }^{\circ} \mathrm{C}$, some (moderate) capture of $\mathrm{Cd}$ in bottom ash was observed, whereas at $900^{\circ} \mathrm{C}$ the release of $\mathrm{Cd}$ from bottom ash was even enhanced, due to experimental temperature exceeding the optimal temperature range of $500{ }^{\circ} \mathrm{C}-650{ }^{\circ} \mathrm{C}$ (releasing retained $\mathrm{Cl}$ back). 
The effect of temperature evaluated by Liu et al. [43] led to a similar conclusion. Sewage sludge conditioned with $\mathrm{FeCl}_{3} / \mathrm{CaO}$ (due to dewatering) was incinerated at $600{ }^{\circ} \mathrm{C}-700{ }^{\circ} \mathrm{C}$ released slightly less $\mathrm{Cd}$ than without conditioner. However, at $800^{\circ} \mathrm{C}-900{ }^{\circ} \mathrm{C}$, sludge with $\mathrm{FeCl}_{3} / \mathrm{CaO}$ released more $\mathrm{Cd}$ [43] — the latter case corresponds with the temperature exceeding the optimal retention range.

According to Li et al. [52], the retention ability of $\mathrm{CaCO}_{3}$ can be improved by $\mathrm{K}_{2} \mathrm{CO}_{3}$ or $\mathrm{Al}_{2}\left(\mathrm{SO}_{4}\right)_{3}$ modification - the defects created during limestone modification enhanced the retention ability.

Results from recent studies indicate that the presence of PVC during the combustion/incineration of coal/waste with $\mathrm{Cd}$ increases its volatility and potential fractions released in emissions. Calcareous additives could suppress this unfavorable effect; but if added directly into the furnace, the temperature is usually too high for efficient retention of chlorination agents $[43,52,68,78,79]$. However, if limestone is applied within a semi-dry spray tower, good Cd retention results were achieved, which was documented by $\mathrm{Chen}$ et al. [57]. Synthetic solid waste (sawdust, PP and Cd-nitrate) was incinerated at $700{ }^{\circ} \mathrm{C}-800{ }^{\circ} \mathrm{C}$ and semi-dry spray tower operate at the temperature of $150^{\circ} \mathrm{C}-170^{\circ} \mathrm{C}$. If no PVC was added in the feed waste, the best $(10 \%) \mathrm{Cd}$ retention results were received by water injection (i.e., no adsorbent). When PVC was added to synthetic waste, absolutely the best overall Cd retention was observed if limestone was used in semi-dry spray tower (nearly $40 \% \mathrm{Cd}$ retention), followed by water $(21 \%)$, kaolinite $(13 \%)$ and $\mathrm{Al}_{2} \mathrm{O}_{3}(10 \%)$. If $\mathrm{NaCl}$ was added to the feed waste, limestone injection exhibited somewhat lower $\mathrm{Cd}$ retention ( $28 \% \mathrm{Cd}$ retention), which was the best result of all adsorbents injected in the experiment with $\mathrm{NaCl}$.

Another promising adsorbent for $\mathrm{Cd}$ retention (if combusted/incinerated with PVC) is $\mathrm{NaHCO}_{3}$ [80]. During rotary kiln incineration $\left(850{ }^{\circ} \mathrm{C}\right)$ of limestone $(200 \mathrm{~kg})$ doped with $2 \mathrm{~kg}$ PVC (with $0.5 \% \mathrm{Cd}^{2+}$ ), overall Cd retention achieved by post-incineration injection of $\mathrm{NaHCO}_{3}$ was $96.3 \%$.

In summary, emissions of $\mathrm{Cd}$ (or potentially of other $\mathrm{HMs}$ ) could be reduced by controlling $\mathrm{Cl}$ content in coal but namely in co-combusted wastes. Other promising approach is to apply adsorbent capturing chlorination gases, e.g., calcareous additives $\left(\mathrm{CaO}, \mathrm{CaCO}_{3}\right.$ etc.). In $\mathrm{FBC}$, such additives are already widely applied. However, they are typically added directly to high-temperature zone where the combustion temperature is ca. $850{ }^{\circ} \mathrm{C}$ which is too high to retain $\mathrm{HCl}$. Therefore, from the perspective of the efficient retention of $\mathrm{Cd}$ (or possibly also other $\mathrm{HMs}$ ), low-temperature application is expected to provide better retention results.

\section{Effect of Moisture}

In addition to different moisture levels in individual coals, even more significant effect can be expected if coal is co-combusted with wastes, from which some typically contain higher moisture levels, such as sewage sludge, agricultural or forest residues, etc. [81,82].

The moisture effect should be also taken into account in the case of oxy-fuel combustion [83] or if coal-water slurry is combusted [84,85]. Different drying methods applied to MSW could also have some effect [86].

\subsection{Effect of Moisture (No Extra Cl Added)}

No noticeable effect of moisture levels on Cd distribution was concluded by Durlak et al. [87] or Morf et al. [88]. Other studies document increasing $\mathrm{Cd}$ emissions with increasing moisture levels [89-91].

During pyrolysis of real MSW, release of Cd gradually increased with increasing moisture levels from $0 \%$ via $30 \%$ up to $65 \%$ [90]. The overall enhancement of $\mathrm{Cd}$ release corresponding to increase of moisture level up to $65 \%$ was ca. $10 \%$ (from $60 \%$ to $70 \%$ ) and it was attributed to prolonged pyrolysis time thereby enhancing the volatility of Cd (and some other HMs) [90].

During incineration (at $950^{\circ} \mathrm{C}$ ) of MSW (paper, flour, cotton, sawdust, polystyrene, $\mathrm{Al}_{2} \mathrm{O}_{3}, \mathrm{SiO}_{2}$ and $\mathrm{Cd}$-acetate) $[89,91]$, original $\mathrm{Cd}$ retention rate in bottom ash (ca. 18\%) moderately decreased with increasing moisture levels (in the former study [89] moisture level increased up to $62 \% \mathrm{H}_{2} \mathrm{O}$ and in 
the latter [91] up to $39.4 \% \mathrm{H}_{2} \mathrm{O}$ ). Prevailing physical aspect of the moisture effect on Cd volatility was concluded in these two studies as well $[89,91]$ and prolonged evaporation and longer combustion time were evaluated as dominant reasons of increased Cd volatility. In these two studies [89,91], the incineration time was set as $6 \mathrm{~min}$; therefore, any prolongation might result in increased Cd volatility. In contrast, if MSW was incinerated by Morf et al. [88], the incineration time of $2 \mathrm{~h}$ was probably long enough to suppress the effect of some further little prolongation due to moisture evaporation. Equilibrium calculations by Durlak et al. [87] evaluated thermodynamic effect of chemical reactions; kinetic effects are not usually included in such studies [92].

\subsection{Effect of Moisture in the Presence of $\mathrm{Cl}$}

$\mathrm{Cd}$ is one of the most volatile elements, which results in typically low remaining fractions in bottom ash after combustion. If extra $\mathrm{Cl}$ is added, $\mathrm{Cd}$ volatility further increases leaving behind only a few $\%$ of $\mathrm{Cd}$ in bottom ash (which somewhat hinders evaluation of the moisture effect).

During synthetic MSW incineration at $950^{\circ} \mathrm{C}$ without extra $\mathrm{Cl}$ added [91], bottom ash retained ca. $18 \%$ of $\mathrm{Cd}$ while if $1 \%$ of $\mathrm{Cl}$ was added, there was practically no retention (<ca. $1-2 \%)$-these data are for $0 \%$ moisture. If $\% \mathrm{H}_{2} \mathrm{O}$ increased up to $39.4 \%$, the retention of Cd in bottom ash slightly increased but still remained quite low (ca. $<5 \%$ ). This effect is in line with thermodynamic equilibrium calculations [91] showing two dominant competitive species: $\mathrm{CdCl}_{2}(\mathrm{~g})$ and $\mathrm{CdO}(\mathrm{s})$. As the fraction of $\mathrm{Cd}(\mathrm{g})$ is within only a few \%, the distribution of $\mathrm{Cd}$ between $\mathrm{CdCl}_{2}(\mathrm{~g})$ and $\mathrm{CdO}(\mathrm{s})$ governs overall $\mathrm{Cd}$ volatility and its release from bottom ash. Specifically, at $950{ }^{\circ} \mathrm{C}$ [91], increase of moisture from 10 to $35 \%$ lead to decrease of $\mathrm{CdCl}_{2}$ (g) fraction by ca. $20 \%$ (and this $\mathrm{Cd}$ fraction is almost totally converted to $\mathrm{CdO}(\mathrm{s})$ because increase of $\mathrm{Cd}(\mathrm{g})$ makes only a few \%). And the conversion of gaseous $\mathrm{CdCl}_{2}$ to condensed $\mathrm{CdO}$ decreases $\mathrm{Cd}$ volatility. Overall, if $\mathrm{Cl}$ is present in sufficient amount in the feed fuel, the volatility enhanced by $\mathrm{Cl}$ prevails on the retention effect brought about by moisture (there are two opposite effects of $\mathrm{Cl}$ and moisture).

\section{Effect of Atmosphere}

\subsection{Effect of $\mathrm{O}_{2}$ Level}

The air/coal ratio is an important factor controlling Cd volatility and emissions [68,92]. According to thermodynamic equilibrium calculations simulating pulverized coal combustion, all $\mathrm{Cd}$ remained in the solid phase at $900 \mathrm{~K}$ if air/coal ratio was at least 1.1; decrease of the air/coal ratio to 1.0 resulted in all $\mathrm{Cd}$ to be in the vapor phase (even at $600 \mathrm{~K}$ ). In the case of FBC, an increase of the air/coal ratio from 1.0 to 1.1 changed $\mathrm{Cd}$ distribution significantly toward its enhanced fractions in the solid phase. Nevertheless, these calculations are based on reaching the chemical equilibrium.

As for the experimental results, it is noteworthy that (at least) 3 different conclusions about effect of $\% \mathrm{O}_{2}$ on Cd volatility can be found in the literature [93-95]:

(i) Decrease of Cd volatility by increased $\% \mathrm{O}_{2}$ (which is consistent with thermodynamic calculations [92]) was concluded for incineration of $\mathrm{Al}_{2} \mathrm{O}_{3}$ impregnated with $\mathrm{CdCl}_{2}$ at $\mathrm{FBC}$ reactor at $850{ }^{\circ} \mathrm{C}$ for $1 \mathrm{~h}$ [93]. The observation was explained via the Reaction (16) [93]:

$$
2 \mathrm{MCl}+\mathrm{Al}_{2} \mathrm{O}_{3}+2 \mathrm{O}_{2} \rightarrow 2 \mathrm{MO}_{2} \cdot \mathrm{Al}_{2} \mathrm{O}_{3}+2 \mathrm{Cl}_{2}
$$

(where increasing $\% \mathrm{O}_{2}$ shifts the equilibrium to the right in favor of the formation of non-volatile $\left.2 \mathrm{MO}_{2} \cdot \mathrm{Al}_{2} \mathrm{O}_{3}\right)$ [93].

As the dwell time in the high-temperature zone was long enough $(1 \mathrm{~h})$, the kinetic limitations were thereby diminished and the experimental reasons are in line with thermodynamic equilibrium calculations.

Thermodynamic equilibrium calculations conducted by Yan et al. [62] concluded different effect of oxidizing/reducing conditions for low-ash coal and high-ash coal. In the case of high-ash coal, volatilization of $\mathrm{Cd}$ in different atmospheres occurs in similar temperature regions (oxidizing 
atmosphere at $550-800 \mathrm{~K}$; reducing at $600-800 \mathrm{~K}$ ) while in the case of low-ash coal, volatilization in oxidizing atmosphere occurs at higher temperatures $(800-1000 \mathrm{~K})$ than in the case of reducing conditions $(600-700 \mathrm{~K})$. In this case, reducing conditions facilitate $\mathrm{Cd}$ volatilization.

(ii) Increasing $\mathrm{Cd}$ volatility with increasing $\% \mathrm{O}_{2}$ in the inlet atmosphere was observed during co-combustion of lignite and waste activated sludge for $30 \mathrm{~min}$ at $1000{ }^{\circ} \mathrm{C}$ in horizontal tube furnace [94]. Vaporization percentage of $\mathrm{Cd}$ increased from ca. $35 \%\left(10 \% \mathrm{O}_{2}\right)$ up to ca. $50 \%\left(30 \% \mathrm{O}_{2}\right)$ and it was explained through enhanced intensity of combustion by higher $\% \mathrm{O}_{2}$ (increasing local temperature to some extent).

(iii) No noticeable effect of $\% \mathrm{O}_{2}$ on Cd volatilization was concluded during the combustion of two coals at $21 \% \mathrm{O}_{2}$ (in $\mathrm{N}_{2}$ ) and $6.35 \% \mathrm{O}_{2}$ (in $\mathrm{N}_{2}$ ) atmospheres at 800 and $900{ }^{\circ} \mathrm{C}$ [95]. The crucible containing the coal was lifted up and down inside the vertical furnace and no matter which temperature was used, $\% \mathrm{O}_{2}$ did not affect $\mathrm{Cd}$ volatility in these two studied coals. It should be mentioned that the weight loss of $\mathrm{Cd}$ (from the coal) was quite low: ca. $35 \%$ was volatilized at both temperatures and $\mathrm{O}_{2}$ levels from the first coal; in the case of the second coal, at $800{ }^{\circ} \mathrm{C}$ ca. $25 \%$ (for both $\mathrm{O}_{2}$ levels) and at $900{ }^{\circ} \mathrm{C}$ ca. $50 \%$ of $\mathrm{Cd}$ was released. As Cd is a typical high-volatility element, the aforementioned volatilized fractions are surprisingly low, which might correspond with the very character of these combustion experiments, as they were conducted with the aim to simulate the initial stage of flame quenching (i.e., during the time needed only for the release of volatile matter, its ignition and burnout). Therefore, some $\mathrm{Cd}$ still remained in the rest of the sample and it could be hypothesized that $\mathrm{O}_{2}$ level is more important for the interaction with the rest of the sample (than for the volatiles burnout).

\subsection{Effect of "the Rest" of the Atmosphere}

Not only $\% \mathrm{O}_{2}$, but also the composition of "the rest" of the combustion/incineration atmosphere can play an important role [78,96], which is studied namely due to oxy-fuel combustion technology where $\mathrm{CO}_{2}$ can be captured due to recycling of the flue gas and oxygen is used instead of air (thereby increasing $\mathrm{CO}_{2}$ content up to $95 \%$ ) [96]. Thus, instead of $\mathrm{N}_{2} / \mathrm{O}_{2}$ atmosphere, $\mathrm{CO}_{2} / \mathrm{O}_{2}$ is used in oxy-fuel combustion.

Thermodynamic equilibrium calculations [97] concluded that distribution of Cd (and other HMs) in oxy-fuel combustion was nearly the same as in the case of air combustion. However, real incineration experiments with synthetic MSW [78] (flour, paper, sawdust, HDPE, texture, rubber, leather and Cd-acetate) in tubular furnace revealed certain differences in Cd volatility in $\mathrm{CO}_{2} / \mathrm{O}_{2}$ and $\mathrm{N}_{2} / \mathrm{O}_{2}$ atmospheres. In both atmospheres, the $\mathrm{Cd}$ residual rates at $1000^{\circ} \mathrm{C}$ were almost zero; at $900{ }^{\circ} \mathrm{C}$ they were nearly the same-ca. $27-28 \%$. However, at $700{ }^{\circ} \mathrm{C}$ and $800{ }^{\circ} \mathrm{C}, \mathrm{Cd}$ residual rates were higher in $\mathrm{CO}_{2} / \mathrm{O}_{2}$ (oxy-fuel atmosphere) than in $\mathrm{N}_{2} / \mathrm{O}_{2}$ (air): ca. $68 \%$ for $\mathrm{CO}_{2} / \mathrm{O}_{2}$ and $52 \%$ for $\mathrm{N}_{2} / \mathrm{O}_{2}$ at $700{ }^{\circ} \mathrm{C}$ and $25 \%\left(\mathrm{CO}_{2} / \mathrm{O}_{2}\right)$ and $22 \%\left(\mathrm{~N}_{2} / \mathrm{O}_{2}\right)$ for $800{ }^{\circ} \mathrm{C}$. The suppressed $\mathrm{Cd}$ volatility in $\mathrm{CO}_{2} / \mathrm{O}_{2}$ was more pronounced at lower temperatures, which was explained through higher specific heat capacity of $\mathrm{CO}_{2}$ than $\mathrm{N}_{2}$ resulting in delaying the ignition of the MSW and lowering the combustion temperature (in the case of $\mathrm{CO}_{2} / \mathrm{O}_{2}$ atmosphere) thereby decreasing the emissions of $\mathrm{Cd}$. As the incineration time was the same for both atmospheres, these results are not contradictory to thermodynamic equilibrium calculations [97] where kinetic limitations are not usually taken into account. Lower volatilization rate of HMs as a result of a lower particle combustion temperature in oxy-fuel combustion (hence affecting the elemental enrichment in ash) was concluded also by Roy and Bhattacharya [98], Font et al. [99], Oboirien et al. [100] or Suriyawong et al. [101].

\section{Effect of $S$}

Thermodynamic equilibrium calculations (under oxidizing conditions) concluded the occurrence of $\mathrm{CdSO}_{4}$ up to ca. $730{ }^{\circ} \mathrm{C}[102]-750{ }^{\circ} \mathrm{C}[103,104]$. Some authors evaluated the maximum temperature of the predominant $\mathrm{CdSO}_{4}$ occurrence to be ca. 600 [37] or $630{ }^{\circ} \mathrm{C}$ [48] (these minor differences probably originate from different interacting components, atmosphere composition and concentrations of $\mathrm{Cd}$ and $\mathrm{SO}_{4}{ }^{2-}$ ). In any case, even during $\mathrm{FBC}$ in power stations (where the combustion temperature is quite 
low-ca. $850{ }^{\circ} \mathrm{C}$ ), $\mathrm{CdSO}_{4}$ (s) is not stable. If the temperature exceeds $600-700^{\circ} \mathrm{C}$ (up to ca. $1000{ }^{\circ} \mathrm{C}$ ), there is a coexistence of multiple phases whose composition is dependent on levels of interacting components. If the presence of chlorides, silica and alumina (along with $\mathrm{S}$ ) is taken into account, there are namely $\mathrm{CdCl}_{2}(\mathrm{~s}), \mathrm{CdAl}_{2} \mathrm{O}_{4}(\mathrm{~s}), \mathrm{CdSiO}_{3}(\mathrm{~s})$ and $\mathrm{CdO}(\mathrm{s})$. Then, the highest temperature $(\mathrm{t}>\mathrm{ca}$. $\left.1000-1100{ }^{\circ} \mathrm{C}\right)$ is characterized by prevalent occurrence of $\mathrm{Cd}(\mathrm{g})$ as the aforementioned species are not stable in this high-temperature region $[102,105,106]$.

At lower temperatures $\left(\mathrm{t}<\mathrm{ca} .600-700^{\circ} \mathrm{C}\right.$ ), $\mathrm{Cd}$ is not the only element that binds sulfates-there are also $\mathrm{Na}_{2} \mathrm{SO}_{4}$ and $\mathrm{CaSO}_{4}$ (as $\mathrm{Na}$ and $\mathrm{Ca}$ are common elements in coal, wastes or desulfurization additives) or $\mathrm{Cr}_{2}\left(\mathrm{SO}_{4}\right)_{3}, \mathrm{HgSO}_{4}, \mathrm{PbSO}_{4}$ etc. [48]. Individual metals bind $\mathrm{S}$ according to their affinities; according to Yao and Naruse [48], if concentration of $S$ is low, alkali metals are preferred to form condensed phases with it and with increasing $\mathrm{S}$ concentration, $\mathrm{Cd}$ followed by $\mathrm{Pb}, \mathrm{Hg}$ and $\mathrm{Cr}$ create their sulfates as well.

Binding energies calculated for interaction between $\mathrm{Cd}_{\text {and }} \mathrm{S}^{2-}, \mathrm{Cl}^{-}$, sulfate and phosphate document quite high values for sulfates and phosphates (in comparison with sulfides and chlorides); it means that is case of co-existence of all these species, the formation of sulfides or chlorides is preferred [69]. This is consistent with moderate increase of \% $\mathrm{Cd}$ in bottom ash during laboratory combustion (at $850^{\circ} \mathrm{C}$ ) of synthetic MSW with Cd-acetate and $\mathrm{S}$ or $\mathrm{Na}_{2} \mathrm{~S}$ added [107].

In any case, theoretic equilibrium calculations indicate that oxidizing conditions and higher temperatures are not favorable for efficient retention of $\mathrm{Cd}$ by $\mathrm{S}$, which is consistent (e.g.,) with experimental results presented by Luan et al. [69] where $S$ added to wastewater sludge combusted at $850{ }^{\circ} \mathrm{C}$ did not changed noticeably the volatilization rate of $\mathrm{Cd}$ (which was ca. $40-41 \%$ no matter if $\mathrm{S}$ was added).

Decrease of $\mathrm{Cd}$ retention by $\mathrm{SO}_{2}$ injection during co-combustion of coal, biomass and waste secondary fuels (in FBC reactor) was reported in the literature as well $[37,57,107]$. Thermal instability of $\mathrm{CdSO}_{4}$ in combination with the combustion temperature of $850{ }^{\circ} \mathrm{C}$ (in laboratory combustor used for synthetic MSW) might be the probable reason why the addition of $\mathrm{Na}_{2} \mathrm{SO}_{4}$ increased \% Cd in flue gas [101].

Nevertheless, there are also studies documenting that adding $\mathrm{Na}_{2} \mathrm{SO}_{4}$ might favour the retention of $\mathrm{Cd}[46,57]$. Chen et al. [46] combusted synthetic solid waste (plastics, sawdust and Cd-nitrate) at $700{ }^{\circ} \mathrm{C}$ in reactor simulating FBC along with 3 different sorbents-kaolinite, bauxite and $\mathrm{Al}_{2} \mathrm{O}_{3}$ (added into the combustion chamber). Retention rate of $\mathrm{Cd}$ on kaolinite, bauxite and $\mathrm{Al}_{2} \mathrm{O}_{3}$ was ca. $8 \%, 13 \%$ and $8 \%$, respectively. If $\mathrm{Na}_{2} \mathrm{SO}_{4}$ was added into the combustion chamber (under the same conditions), $\mathrm{Cd}$ retention efficiency increased up to $25 \%, 21 \%$ and $34 \%$. It means that the most efficient capture of $\mathrm{Cd}$ was achieved by adding $\mathrm{Na}_{2} \mathrm{SO}_{4}$ and $\mathrm{Al}_{2} \mathrm{O}_{3}$ to synthetic solid waste (directly at combustion chamber with $700{ }^{\circ} \mathrm{C}$ ). Without $\mathrm{Na}_{2} \mathrm{SO}_{4}$, the best retention was achieved by bauxite (ca. $13 \%$ ), which is still quite low in comparison with combined effect of $\mathrm{Na}_{2} \mathrm{SO}_{4}-\mathrm{Al}_{2} \mathrm{O}_{3}$.

Chen et al. [57] published later the results of other similar experiment. Synthetic solid waste (plastics, sawdust and Cd-nitrate) was combusted at $700{ }^{\circ} \mathrm{C}$ in the reactor simulating fluidized-bed incineration. In this case, a semi-dry spray tower $\left(150-170^{\circ} \mathrm{C}\right)$ was installed for injection of water with $4 \%$ of kaolinite, $\mathrm{Al}_{2} \mathrm{O}_{3}$, limestone or without any adsorbent. The best overall retention of $\mathrm{Cd}$ was observed if no adsorbent (i.e., only $\mathrm{H}_{2} \mathrm{O}$ injection in semi-dry spray tower) was used-ca. $10 \%$. When $\mathrm{Na}_{2} \mathrm{SO}_{4}$ was added to the feed waste, overall $\mathrm{Cd}$ retention increased up to $50 \%$ if combined with limestone injection. If no adsorbent was used, $\mathrm{Na}_{2} \mathrm{SO}_{4}$ itself increased the $\mathrm{Cd}$ retention from ca. $10 \%$ to ca. $13 \%$. If limestone adsorbent was used without addition of $\mathrm{Na}_{2} \mathrm{SO}_{4}$ to the feed waste, the retention was even worse $(<5 \%)$. Therefore, there is a synergic effect of $\mathrm{Na}_{2} \mathrm{SO}_{4}$ and limestone that efficiently increase $\mathrm{Cd}$ retention.

$\mathrm{Yu}$ et al. [93] observed significant increase of $\mathrm{Cd}$ vaporization when $\mathrm{SO}_{2}$ was added into $\mathrm{N}_{2}$ atmosphere in $\mathrm{FBC}$ reactor (at $850^{\circ} \mathrm{C}$ ) during combustion of $\mathrm{CdCl}_{2}$-impregnated porous $\mathrm{Al}_{2} \mathrm{O}_{3}$ matrix. After $30-$ min incineration time ca. $30 \% \mathrm{Cd}$ was vaporized in pure $\mathrm{N}_{2}$; if $2000 \mathrm{ppm} \mathrm{SO}_{2}$ and $5000 \mathrm{ppm}$ $\mathrm{SO}_{2}$ was present, vaporization percentage of $\mathrm{Cd}$ increased up to $90 \%$ and $95 \%$. It is interesting that 
the effect on $\mathrm{Pb}$ was much lower (vaporization did not exceed 20\%) and $\mathrm{Zn}$ and $\mathrm{Cu}$ did not show any significant evaporation.

It is known that sulfate phase may be formed at low temperature in the presence of $S$; at higher temperatures it does not play a significant role as $\mathrm{CdSO}_{4}$ is decomposed at $\mathrm{t}>850^{\circ} \mathrm{C}[93,108]$.

\section{Effect of $P$}

Binding energy for interaction between $\mathrm{Cd}$ and phosphate is the highest from the energies related to $\mathrm{Cl}^{-}, \mathrm{S}^{2-}$ and sulfate. Natural levels of $\mathrm{P}$ in most coals are low (200-250 ppm) [22]. Nevertheless, the major advantage of phosphates is their high thermal stability (unlike e.g., sulfates).

If $\mathrm{P}$ content in wastewater sludge was increased from $3.2 \%$ to $7 \% \mathrm{P}$ (in the form of $\mathrm{P}_{2} \mathrm{O}_{5}$ ), $\mathrm{Cd}$ volatilization at $850{ }^{\circ} \mathrm{C}$ decreased from $40 \%$ to ca. $17 \%$ [69]. Promising results were presented also for sediment combustion (at $600{ }^{\circ} \mathrm{C}$ and $850{ }^{\circ} \mathrm{C}$ ) previously treated with phosphoric acid $\left(4.50 \mathrm{PO}_{4}{ }^{3-}\right.$ ). $\mathrm{Cd}$ vaporization $\%$ almost does not change with temperature increase from 600 to $850^{\circ} \mathrm{C}(15$ and $17 \%$ vaporized) [80].

\section{Conclusions}

Concentrations of Cd in coal are quite low (0.033-0.64 ppm) [23]; however, (e.g.,) in MSW or municipal wastewater sludge it can be significantly higher: 0-90 and ca. $100 \mathrm{ppm}$, respectively [23]. In contrast, desulfurization additives as limestone (ca. $0.01 \mathrm{ppm} \mathrm{Cd)}$ or urea (ca. $0.03 \mathrm{ppm} \mathrm{Cd}$ ) might exhibit diluting effect on Cd concentrations [25]. In coal, $\mathrm{Cd}$ is associated with mono/disulfides with some minor occurrence in organic matter or (alumino)silicates. Due to high Cd volatility (with exception of typically minor (alumino)silicate-bound fraction), most $C d$ is easily volatilized and exhibit potential risk of being emitted to surrounding atmosphere either in gaseous form or in sub-micron particles. Therefore, particular attention is paid to mitigating these emissions.

Different approaches for decreasing emissions could be used: pre-combustion treatment, mid-combustion or post-combustion control [52].

Within the pre-combustion treatment, increase of $\mathrm{Cd}$ retention was achieved by $\mathrm{H}_{3} \mathrm{PO}_{4}$ treatment [69].

For their use in high-temperature (i.e., in-furnace) regime, kaolinite [54] and bauxite [50] exhibited promising results at $1100-1200^{\circ} \mathrm{C}$. Moreover, $\mathrm{Cd}$ retained within high-temperature capture (typically by melted or at least agglomerated particles) should be more resistant to leaching than $\mathrm{Cd}$ physically sorbed/condensed during low-temperature regime. For the commonly used desulfurization adsorbents ( $\mathrm{CaO}$, limestone etc.) exhibiting efficient retention of $\mathrm{S}$ and other elements (e.g., As) [8], even FBC temperature might be too high to provide efficient retention of chlorination agents that otherwise enhance $\mathrm{Cd}$ (and some other $\mathrm{HMs}$ ) volatility. Optimal temperature range in this case is $500-700{ }^{\circ} \mathrm{C}[43,68,75,76]$. Lower temperatures typically also favor $\mathrm{Cd}$ retention by $\mathrm{S}[37,48,102]$.

Post-combustion treatment of flue gas (using adsorbents in low-temperature regime) has also been tested. Promising results has been achieved using semi-dry spray tower working at $150-170{ }^{\circ} \mathrm{C}$ [57] spraying suspension of $5 \%$ adsorbent (in water). The adsorbents were efficient for most HMs but in the case of $\mathrm{Cd}$ the best results have been observed if water without adsorbents was used.

Detailed information related to thermodynamic distribution of individual Cd (or other HMs) species in dependence on temperature, atmosphere, interacting-species concentrations etc. can be found in the literature. These calculations are often in line with laboratory experiments, namely if combustion/incineration/adsorption dwell time is long enough. Nevertheless, as typical coal combustion in power stations provides (at maximum) a few minutes in high-temperature zone, future trend (in mitigating HMs emissions) could be directed toward the evaluation of time factor, i.e., the kinetic aspect of the HMs volatilization/retention.

In any case, using pre-combustion treatment or in-furnace additives/adsorbents changes the composition and other characteristics of combustion (incineration) ashes, which may significantly affect their further technological utilization or environmental impact (e.g., leaching). Similarly, using 
low-temperature adsorbents may either affect the fly ash quality or even create new wastes. All these alternatives should be taken into account as studies evaluating these aspects are currently quite scarce. The effect on fouling/slagging could be evaluated as well. Mitigating emissions of HMs is not the only challenge related to the coal combustion; new technologies are developed to decrease emissions of $\mathrm{CO}_{2}$, $\mathrm{NO}_{\mathrm{x}}$ and other pollutants and distribution of HMs under these conditions should be evaluated as well.

Author Contributions: Conceptualization, literature search and evaluation, writing and editing, L.B.; funding acquisition, project administration and consultations during manuscript preparation, H.R. and M.K.; consultations on industrial coal combustion, B.Č. All authors have read and agreed to the published version of the manuscript.

Funding: This research was funded by the Ministry of Education, Youth and Sport of the Czech Republic by the research projects: CZ.1.05/2.1.00/19.0389: Research Infrastructure Development of the CENET and SP2020/22 "Innovative methods for monitoring particulate matter from combustion processes".

Conflicts of Interest: The authors declare no conflict of interest.

\section{References}

1. Parzentny, H.R.; Róg, L. The Role of Mineral Matter in Concentrating Uranium and Thorium in Coal and Combustion Residues from Power Plants in Poland. Minerals 2019, 9, 312. [CrossRef]

2. Wagner, N.; Matiane, A. Rare earth elements in select Main Karoo Basin (South Africa) coal and coal ash samples. Int. J. Coal Geol. 2018, 196, 82-92. [CrossRef]

3. Hower, J.C.; Granite, E.J.; Mayfield, D.B.; Lewis, A.S.; Finkelman, R.B. Notes on Contributions to the Science of Rare Earth Element Enrichment in Coal and Coal Combustion Byproducts. Minerals 2016, 6, 32. [CrossRef]

4. Bartoňová, L.; Serenčíšová, J.; Čech, B. Yttrium partitioning and associations in coal-combustion ashes prior to and after their leaching in HCl. Fuel Process. Technol. 2018, 173, 205-215. [CrossRef]

5. Klika, Z.; Ambružová, L.; Sýkorová, I.; Seidlerová, J.; Kolomazník, I. Critical evaluation of sequential extraction and sink-float methods used for the determination of Ga and Ge affinity in lignite. Fuel 2009, 88, 1834-1841. [CrossRef]

6. Raclavská, H.; Matýsek, D.; Raclavský, K.; Juchelková, D. Geochemistry of fly ash from desulphurisation process performed by sodium bicarbonate. Fuel Process. Technol. 2010, 91, 150-157. [CrossRef]

7. Scala, F.; Chirone, R.; Meloni, P.; Carcangiu, G.; Manca, M.; Mulas, G.; Mulas, A. Fluidized bed desulfurization using lime obtained after slow calcination of limestone particles. Fuel 2013, 114, 99-105. [CrossRef]

8. Bartoňová, L.; Klika, Z. Effect of $\mathrm{CaO}$ on retention of $\mathrm{S}, \mathrm{Cl}, \mathrm{Br}, \mathrm{As}, \mathrm{Mn}, \mathrm{V}, \mathrm{Cr}, \mathrm{Ni}, \mathrm{Cu}, \mathrm{Zn}, \mathrm{W}$ and $\mathrm{Pb}$ in bottom ashes from fluidized-bed coal combustion power station. J. Environ. Sci. 2014, 26, 1429-1436. [CrossRef]

9. Scala, F.; Cimino, S. Elemental mercury capture and oxidation by a regenerable manganese-based sorbent: The effect of gas composition. Chem. Eng. J. 2015, 278, 134-139. [CrossRef]

10. Bartoňová, L. Unburned carbon from coal combustion ash: An overview. Fuel Process. Technol. 2015, 134, 136-158. [CrossRef]

11. Hower, J.C.; Groppo, J.G.; Graham, U.M.; Ward, C.R.; Kostova, I.J.; Maroto-Valer, M.M.; Dai, S. Coal-derived unburned carbons in fly ash: A review. Int. J. Coal Geol. 2017, 179, 11-27. [CrossRef]

12. Wagner, N.; Hlatshwayo, B. The occurrence of potentially hazardous trace elements in five Highveld coals, South Africa. Int. J. Coal Geol. 2005, 63, 228-246. [CrossRef]

13. Scala, F.; Chirone, R.; Lancia, A. Elemental mercury vapor capture by powdered activated carbon in a fluidized bed reactor. Fuel 2011, 90, 2077-2082. [CrossRef]

14. Hower, J.C.; Robl, T.; Anderson, C.; Thomas, G.; Sakulpitakphon, T.; Mardon, S.; Clark, W. Characteristics of coal combustion products (CCP's) from Kentucky power plants, with emphasis on mercury content. Fuel 2005, 84, 1338-1350. [CrossRef]

15. Senior, C.L.; Johnson, S.A. Impact of Carbon-in-Ash on Mercury Removal across Particulate Control Devices in Coal-Fired Power Plants. Energy Fuels 2005, 19, 859-863. [CrossRef]

16. Antón, M.A.L.; Diaz-Somoano, M.; Fierro, J.; Martinez-Tarazona, M.R. Retention of arsenic and selenium compounds present in coal combustion and gasification flue gases using activated carbons. Fuel Process. Technol. 2007, 88, 799-805. [CrossRef] 
17. Seames, W.S.; Wendt, J.O. Partitioning of arsenic, selenium, and cadmium during the combustion of Pittsburgh and Illinois \#6 coals in a self-sustained combustor. Fuel Process. Technol. 2000, 63, 179-196. [CrossRef]

18. Bartoňová, L.; Raclavská, H.; Čech, B.; Kucbel, M. Behavior of Pb During Coal Combustion: An Overview. Sustainability 2019, 11, 6061. [CrossRef]

19. Tun, M.M.; Juchelková, D.; Raclavská, H.; Sassmanová, V. Utilization of Biodegradable Wastes as a Clean Energy Source in the Developing Countries: A Case Study in Myanmar. Energies 2018, 11, 3183. [CrossRef]

20. Hoornweg, D.; Bhada-Tata, P. What a Waste: A Global Review of Solid Waste Management; Urban Development Series Knowledge Papers; The World Bank Group: Washington, DC, USA, 2012; pp. 1-98.

21. Tun, M.M.; Juchelková, D. Assessment of solid waste generation and greenhouse gas emission potential in Yangon city, Myanmar. J. Mater. Cycles Waste Manag. 2018, 20, 1397-1408. [CrossRef]

22. Ketris, M.; Yudovich, Y. Estimations of Clarkes for Carbonaceous biolithes: World averages for trace element contents in black shales and coals. Int. J. Coal Geol. 2009, 78, 135-148. [CrossRef]

23. Biswas, P.; Wu, C.Y. Control of toxic metal emissions from combustors using sorbents: A review. J. Air Waste Manag. Assoc. 1998, 48, 113-127. [CrossRef] [PubMed]

24. Nowak, B.; Aschenbrenner, P.; Winter, F. Heavy metal removal from sewage sludge ash and municipal solid waste fly ash-A comparison. Fuel Process. Technol. 2013, 105, 195-201. [CrossRef]

25. Fu, B.; Liu, G.; Sun, M.; Hower, J.C.; Mian, M.; Wu, D.; Wang, R.; Hu, G. Emission and transformation behavior of minerals and hazardous trace elements (HTEs) during coal combustion in a circulating fluidized bed boiler. Environ. Pollut. 2018, 242, 1950-1960. [CrossRef]

26. Fu, B.; Liu, G.; Sun, M.; Hower, J.C.; Hu, G.; Wu, D. A comparative study on the mineralogy, chemical speciation, and combustion behavior of toxic elements of coal beneficiation products. Fuel 2018, 228, 297-308. [CrossRef]

27. Wang, Y.; Tang, Y.; Liu, S.; Wang, Y.; Finkelman, R.B.; Wang, B.; Guo, X. Behavior of trace elements and mineral transformations in the super-high organic sulfur Ganhe coal during gasification. Fuel Process. Technol. 2018, 177, 140-151. [CrossRef]

28. Finkelman, R.B.; Palmer, C.A.; Wang, P. Quantification of the modes of occurrence occurrence of 42 elements in coal. Int. J. Coal Geol. 2018, 185, 138-160. [CrossRef]

29. Wagner, N.; Tlotleng, M. Distribution of selected trace elements in density fractionated Waterberg coals from South Africa. Int. J. Coal Geol. 2012, 94, 225-237. [CrossRef]

30. Parzentny, H.R.; Róg, L. Distribution of Some Ecotoxic Elements in Fuel and Solid Combustion Residues in Poland. Energies 2020, 13, 1131. [CrossRef]

31. Yudovich, Y.; Ketris, M. Chlorine in coal: A review. Int. J. Coal Geol. 2006, 67, 127-144. [CrossRef]

32. Vassilev, S. Contents, modes of occurrence and origin of chlorine and bromine in coal. Fuel 2000, 79, 903-921. [CrossRef]

33. Ohenoja, K.; Pesonen, J.; Yliniemi, J.; Illikainen, M. Utilization of Fly Ashes from Fluidized Bed Combustion: A Review. Sustainability 2020, 12, 2988. [CrossRef]

34. Vassilev, S.V.; Vassileva, C.G.; Vassilev, V.S. Advantages and disadvantages of composition and properties of biomass in comparison with coal: An overview. Fuel 2015, 158, 330-350. [CrossRef]

35. Růžičková, J.; Raclavská, H.; Kucbel, M.; Grobelak, A.; Šafář, M.; Raclavský, K.; Švédová, B.; Juchelková, D.; Moustakas, K. The potential environmental risks of the utilization of composts from household food waste. Environ. Sci. Pollut. Res. 2020, 1-17. [CrossRef]

36. Corsaro, A.; Raclavská, H.; Hlavsová, A.; Frydrych, J.; Juchelková, D. Perennial grasses as prospective energy sources. Energy Sources Part A Recover. Util. Environ. Eff. 2016, 38, 1206-1211. [CrossRef]

37. Diaz-Somoano, M.; Unterberger, S.; Hein, K. Prediction of trace element volatility during co-combustion processes. Fuel 2006, 85, 1087-1093. [CrossRef]

38. Youcai, Z.; Stucki, S.; Ludwig, C.; Wochele, J. Impact of moisture on volatility of heavy metals in municipal solid waste incinerated in a laboratory scale simulated incinerator. Waste Manag. 2004, 24, 581-587. [CrossRef]

39. Kovacs, H.; Szemmelveisz, K.; Koós, T. Theoretical and experimental metals flow calculations during biomass combustion. Fuel 2016, 185, 524-531. [CrossRef] 
40. Perry, D.L. Handbook of Inorganic Compounds, 2nd ed.; CRC Press: Boca Raton, FL, USA, 2011 ; p. 581. ISBN 9781439814611.

41. Chan, C.; Jia, C.Q.; Graydon, J.W.; Kirk, D.W. The behaviour of selected heavy metals in MSW incineration electrostatic precipitator ash during roasting with chlorination agents. J. Hazard. Mater. 1996, 50, 1-13. [CrossRef]

42. Yu, J.; Qiao, Y.; Jin, L.; Ma, C.; Paterson, N.; Sun, L. Removal of toxic and alkali/alkaline earth metals during co-thermal treatment of two types of MSWI fly ashes in China. Waste Manag. 2015, 46, 287-297. [CrossRef]

43. Liu, J.; Zeng, J.; Sun, S.; Huang, S.; Kuo, J.; Chen, N. Combined effects of $\mathrm{FeCl}_{3}$ and $\mathrm{CaO}$ conditioning on $\mathrm{SO}_{2}$, $\mathrm{HCl}$ and heavy metals emissions during the DDSS incineration. Chem. Eng. J. 2016, 299, 449-458. [CrossRef]

44. Linak, W.P.; Wendt, J.O. Toxic metal emissions from incineration: Mechanisms and control. Prog. Energy Combust. Sci. 1993, 19, 145-185. [CrossRef]

45. Scotto, M.V.; Uberoi, M.; Peterson, T.W.; Shadman, F.; Wendt, J.O. Metal capture by sorbents in combustion processes. Fuel Process. Technol. 1994, 39, 357-372. [CrossRef]

46. Chen, J.-C.; Wey, M.-Y.; Lin, Y.-C. The adsorption of heavy metals by different sorbents under various incineration conditions. Chemosphere 1998, 37, 2617-2625. [CrossRef]

47. Ho, T.C.; Chuang, T.C.; Chelluri, S.; Lee, Y.; Hopper, J.R. Simultaneous capture of metal, sulfur and chlorine by sorbents during fluidized bed incineration. Waste Manag. 2001, 21, 435-441. [CrossRef]

48. Yao, H.; Naruse, I. Using sorbents to control heavy metals and particulate matter emission during solid fuel combustion. Particuology 2009, 7, 477-482. [CrossRef]

49. Yao, H.; Mkilaha, I.S.; Naruse, I. Screening of sorbents and capture of lead and cadmium compounds during sewage sludge combustion. Fuel 2004, 83, 1001-1007. [CrossRef]

50. Cheng, J.F.; Zeng, H.C.; Zhang, Z.H.; Xu, M.H. The effects of solid absorbents on the emission of trace elements, SO2, and NOx during coal combustion. Int. J. Energy Res. 2001, 25, 1043-1052. [CrossRef]

51. Chen, J.; Sun, Y.; Shao, N.; Zhang, Z. Environmental mitigation of sludge combustion via two opposite modifying strategies: Kinetics and stabilization effect. Fuel 2018, 227, 346-354. [CrossRef]

52. Li, S.; Guo, S.; Huang, X.; Huang, T.; Niazi, N.K.; Muhammad, F.; Xu, G.; Zhao, Z.; Yu, L.; Yan, Y.; et al. Research on characteristics of heavy metals (As, Cd, $\mathrm{Zn}$ ) in coal from Southwest China and prevention method by using modified calcium-based materials. Fuel 2016, 186, 714-725. [CrossRef]

53. Kuo, J.-H.; Lin, C.-L.; Wey, M.-Y. Effect of particle agglomeration on heavy metals adsorption by Al- and Ca-based sorbents during fluidized bed incineration. Fuel Process. Technol. 2011, 92, 2089-2098. [CrossRef]

54. Wendt, J.O.L.; Lee, S.J. High-temperature sorbents for $\mathrm{Hg}, \mathrm{Cd}, \mathrm{Pb}$, and other trace metals: Mechanisms and applications. Fuel 2010, 89, 894-903. [CrossRef]

55. Peng, T.-H.; Lin, C.-L. Influence of various chlorine additives on the partitioning of heavy metals during low-temperature two-stage fluidized bed incineration. J. Environ. Manag. 2014, 146, 362-368. [CrossRef] [PubMed]

56. Chen, J.-C.; Wey, M.-Y.; Yan, M.-H. Theoretical and Experimental Study of Metal Capture during Incineration Process. J. Environ. Eng. 1997, 123, 1100-1106. [CrossRef]

57. Chen, J.-C.; Wey, M.-Y.; Ou, W.-Y. Capture of heavy metals by sorbents in incineration flue gas. Sci. Total Environ. 1999, 228, 67-77. [CrossRef]

58. Chiang, B.-C.; Wey, M.-Y.; Yeh, C.-L. Control of acid gases using a fluidized bed adsorber. J. Hazard. Mater. 2003, 101, 259-272. [CrossRef]

59. Wey, M.-Y.; Chen, K.-H.; Liu, K.-Y. The effect of ash and filter media characteristics on particle filtration efficiency in fluidized bed. J. Hazard. Mater. 2005, 121, 175-181. [CrossRef]

60. Folgueras, M.B.; Folgueras-Díaz, M.; Xiberta, A.J.; Alonso, M. Effect of Inorganic Matter on Trace Element Behavior during Combustion of Coal-Sewage Sludge Blends. Energy Fuels 2007, 21, 744-755. [CrossRef]

61. Danihelka, P.; Volna, Z.; Jones, J.; Williams, A. Emission of trace toxic metals during pulverized fuel combustion of Czech coals. Int. J. Energy Res. 2003, 27, 1181-1203. [CrossRef]

62. Yan, R.; Gauthier, D.; Flamant, G. Volatility and chemistry of trace elements in a coal combustor. Fuel 2001, 80, 2217-2226. [CrossRef]

63. Raclavská, H.; Corsaro, A.; Hartmann-Koval, S.; Juchelková, D. Enrichment and distribution of 24 elements within the sub-sieve particle size distribution ranges of fly ash from wastes incinerator plants. J. Environ. Manag. 2017, 203, 1169-1177. [CrossRef] [PubMed] 
64. Chiang, K.-Y.; Wang, K.-S.; Lin, F.-L.; Chu, W.-T. Chloride effects on the speciation and partitioning of heavy metal during the municipal solid waste incineration process. Sci. Total Environ. 1997, 203, 129-140. [CrossRef]

65. Huang, Y.J.; Jin, B.S.; Zhong, Z.P.; Xiao, R.; Tang, Z.Y.; Ren, H.F. Emission features of several trace elements in pulverized coal boiler. In Proceedings of the International Conference on Energy and the Environment, Shanghai, China, 11-13 December 2003; Volume 1-2, pp. 562-568, ISBN 7-5323-7335-5.

66. Wu, H.; Glarborg, P.; Frandsen, F.J.; Dam-Johansen, K.; Jensen, P.A.; Sander, B. Trace elements in co-combustion of solid recovered fuel and coal. Fuel Process. Technol. 2013, 105, 212-221. [CrossRef]

67. Qi, X.; Song, G.; Yang, S.; Yang, Z.; Lyu, Q. Migration and transformation of sodium and chlorine in high-sodium high-chlorine Xinjiang lignite during circulating fluidized bed combustion. J. Energy Inst. 2019, 92, 673-681. [CrossRef]

68. Wang, X.; Huang, Y.; Liu, C.; Zhang, S.; Wang, Y.; Piao, G. Dynamic volatilization behavior of Pb and Cd during fixed bed waste incineration: Effect of chlorine and calcium oxide. Fuel 2017, 192, 1-9. [CrossRef]

69. Luan, J.; Li, R.; Zhang, Z.; Li, Y.; Zhao, Y. Influence of chlorine, sulfur and phosphorus on the volatilization behavior of heavy metals during sewage sludge thermal treatment. Waste Manag. Res. 2013, 31, 1012-1018. [CrossRef] [PubMed]

70. Wang, K.-S.; Chiang, K.-Y.; Tsai, C.C.; Sun, C.-J.; Lin, K.-L.; Tsai, C.-C.; Tsai, C.-C. The effects of FeCl3 on the distribution of the heavy metals $\mathrm{Cd}, \mathrm{Cu}, \mathrm{Cr}$, and $\mathrm{Zn}$ in a simulated multimetal incineration system. Environ. Int. 2001, 26, 257-263. [CrossRef]

71. Nowak, B.; Rocha, S.F.; Aschenbrenner, P.; Rechberger, H.; Winter, F. Heavy metal removal from MSW fly ash by means of chlorination and thermal treatment: Influence of the chloride type. Chem. Eng. J. 2012, 179, 178-185. [CrossRef]

72. Yan, R.; Gauthier, D.; Flamant, G. Partitioning of trace elements in the flue gas from coal combustion. Combust. Flame 2001, 125, 942-954. [CrossRef]

73. Yu, J.; Sun, L.; Ma, C.; Qiao, Y.; Yao, H. Thermal degradation of PVC: A review. Waste Manag. 2016, 48, 300-314. [CrossRef]

74. Saeed, L.; Tohka, A.; Haapala, M.; Zevenhoven, R. Pyrolysis and combustion of PVC, PVC-wood and PVC-coal mixtures in a two-stage fluidized bed process. Fuel Process. Technol. 2004, 85, 1565-1583. [CrossRef]

75. Chyang, C.-S.; Han, Y.-L.; Zhong, Z.-C. Study of HCl Absorption by CaO at High Temperature. Energy Fuels 2009, 23, 3948-3953. [CrossRef]

76. Bie, R.; Li, S.; Yang, L. Reaction mechanism of $\mathrm{CaO}$ with $\mathrm{HCl}$ in incineration of wastewater in fluidized bed. Chem. Eng. Sci. 2005, 60, 609-616. [CrossRef]

77. Zhu, H.; Jiang, X.; Yan, J.; Chi, Y.; Cen, K. TG-FTIR analysis of PVC thermal degradation and $\mathrm{HCl}$ removal. J. Anal. Appl. Pyrolysis 2008, 82, 1-9. [CrossRef]

78. Tang, X.; Chen, F.; Shao, D.; Qin, P. Effects of $\mathrm{CaO}$ and $\mathrm{CaCO} 3$ on Heavy Metal Capture in Bottom Ash during Municipal Solid Waste Combustion under a CO2/O2 Atmosphere. Energy Fuels 2017, 31, 10998-11006. [CrossRef]

79. Font, O.; Querol, X.; Izquierdo, M.; Alvarez, E.; Moreno, N.; Díez, S.; Álvarez-Rodríguez, R.; Clemente-Jul, C.; Coca, P.; Garcia-Peña, F. Partitioning of elements in a entrained flow IGCC plant: Influence of selected operational conditions. Fuel 2010, 89, 3250-3261. [CrossRef]

80. Rio, S.; Verwilghen, C.; Ramaroson, J.; Ange, N.; Sharrock, P. Heavy metal vaporization and abatement during thermal treatment of modified wastes. J. Hazard. Mater. 2007, 148, 521-528. [CrossRef] [PubMed]

81. Raclavská, H.; Juchelková, D.; Roubíček, V.; Matýsek, D. Energy utilisation of biowaste-Sunflower-seed hulls for co-firing with coal. Fuel Process. Technol. 2011, 92, 13-20. [CrossRef]

82. Raclavská, H.; Juchelková, D.; Škrobánková, H.; Wiltowski, T.; Campen, A. Conditions for energy generation as an alternative approach to compost utilization. Environ. Technol. 2011, 32, 407-417. [CrossRef]

83. Roy, B.; Choo, W.L.; Bhattacharya, S. Prediction of distribution of trace elements under Oxy-fuel combustion condition using Victorian brown coals. Fuel 2013, 114, 135-142. [CrossRef]

84. Vershinina, K.Y.; Egorov, R.I.; Strizhak, P.A. The ignition parameters of the coal-water slurry droplets at the different methods of injection into the hot oxidant flow. Appl. Therm. Eng. 2016, 107, 10-20. [CrossRef]

85. Glushkov, D.O.; Shabardin, D.P.; Strizhak, P.A.; Vershinina, K.Y. Influence of organic coal-water fuel composition on the characteristics of sustainable droplet ignition. Fuel Process. Technol. 2016, 143, 60-68. [CrossRef] 
86. Tun, M.M.; Juchelková, D. Drying methods for municipal solid waste quality improvement in the developed and developing countries: A review. Environ. Eng. Res. 2018, 24, 529-542. [CrossRef]

87. Durlak, S.K.; Biswas, P.; Shi, J. Equilibrium analysis of the affect of temperature, moisture and sodium content on heavy metal emissions from municipal solid waste incinerators. J. Hazard. Mater. 1997, 56, 1-20. [CrossRef]

88. Morf, L.S.; Brunner, P.H.; Spaun, S. Effect of operating conditions and input variations on the partitioning of metals in a municipal solid waste incinerator. Waste Manag. Res. 2000, 18, 4-15. [CrossRef]

89. Meng, A.; Li, Q.; Jia, J.; Zhang, Y. Effect of Moisture on Partitioning of Heavy metals in Incineration of Municipal Solid Waste. Chinese J. Chem. Eng. 2012, 20(5), 1008-1015. [CrossRef]

90. Raclavská, H.; Corsaro, A.; Hlavsová, A.; Juchelková, D.; Zajonc, O. The effect of moisture on the release and enrichment of heavy metals during pyrolysis of municipal solid waste. Waste Manag. Res. 2015, 33, 267-274. [CrossRef]

91. Li, Q.; Meng, A.; Jia, J.; Zhang, Y. Investigation of heavy metal partitioning influenced by flue gas moisture and chlorine content during waste incineration. J. Environ. Sci. 2010, 22, 760-768. [CrossRef]

92. Furimsky, E. Characterization of trace element emissions from coal combustion by equilibrium calculations. Fuel Process. Technol. 2000, 63, 29-44. [CrossRef]

93. Yu, J.; Sun, L.; Xiang, J.; Hu, S.; Su, S.; Qiu, J. Vaporization of heavy metals during thermal treatment of model solid waste in a fluidized bed incinerator. Chemosphere 2012, 86, 1122-1126. [CrossRef]

94. Wang, R.; Zhao, Z.; Yin, Q.; Liu, J. Mineral transformation and emission behaviors of Cd, Cr, Ni, Pb and Zn during the co-combustion of dried waste activated sludge and lignite. Fuel 2017, 199, 578-586. [CrossRef]

95. Zhang, J.; Han, C.-L.; Xu, Y.-Q. The release of the hazardous elements from coal in the initial stage of combustion process. Fuel Process. Technol. 2003, 84, 121-133. [CrossRef]

96. Oboirien, B.O.; Thulari, V.; North, B. Enrichment of trace elements in bottom ash from coal oxy-combustion: Effect of coal types. Appl. Energy 2016, 177, 81-86. [CrossRef]

97. Zheng, L.; Furimsky, E. Assessment of coal combustion in $\mathrm{O} 2+\mathrm{CO} 2$ by equilibrium calculations. Fuel Process. Technol. 2003, 81, 23-34. [CrossRef]

98. Roy, B.; Bhattacharya, S. Oxy-fuel fluidized bed combustion using Victorian brown coal: An experimental investigation. Fuel Process. Technol. 2014, 117, 23-29. [CrossRef]

99. Font, O.; Cordoba, P.; Leiva, C.; Romeo, L.; Bolea, I.; Guedea, I.; Moreno, N.; Querol, X.; Fernández, C.L.; Diez, L. Fate and abatement of mercury and other trace elements in a coal fluidised bed oxy combustion pilot plant. Fuel 2012, 95, 272-281. [CrossRef]

100. Oboirien, B.O.; Thulari, V.; North, B. Major and trace elements in coal bottom ash at different oxy coal combustion conditions. Appl. Energy 2014, 129, 207-216. [CrossRef]

101. Suriyawong, A.; Gamble, M.; Lee, M.-H.; Axelbaum, R.; Biswas, P. Submicrometer Particle Formation and Mercury Speciation Under O2-CO2Coal Combustion. Energy Fuels 2006, 20, 2357-2363. [CrossRef]

102. Zhang, Y.; Chen, Y.; Meng, A.; Li, Q.; Cheng, H. Experimental and thermodynamic investigation on transfer of cadmium influenced by sulfur and chlorine during municipal solid waste (MSW) incineration. J. Hazard. Mater. 2008, 153, 309-319. [CrossRef]

103. Zhao, S.; Duan, Y.; Lu, J.; Liu, S.; Pudasainee, D.; Gupta, R.; Liu, M.; Lu, J. Enrichment characteristics, thermal stability and volatility of hazardous trace elements in fly ash from a coal-fired power plant. Fuel 2018, 225, 490-498. [CrossRef]

104. Zhao, S.; Duan, Y.; Li, Y.; Liu, M.; Lu, J.; Ding, Y.; Gu, X.; Tao, J.; Du, M. Emission characteristic and transformation mechanism of hazardous trace elements in a coal-fired power plant. Fuel 2018, 214, 597-606. [CrossRef]

105. Salgansky, E.A.; Podlesniy, D.N.; Tsvetkov, M.V.; Zaichenko, A.Y. Thermodynamic Estimating the Mass Transfer of Compounds of Rare Metals under Conditions of a Filtration Combustion Wave. Russ. J. Appl. Chem. 2020, 93, 1096-1101. [CrossRef]

106. Liu, J.; Falcoz, Q.; Gauthier, D.; Flamant, G.; Zheng, C. Volatilization behavior of Cd and Zn based on continuous emission measurement of flue gas from laboratory-scale coal combustion. Chemosphere 2010, 80, 241-247. [CrossRef] 
107. Miller, B.B.; Kandiyoti, R.; Dugwell, D.R. Trace Element Emissions from Co-combustion of Secondary Fuels with Coal: A Comparison of Bench-Scale Experimental Data with Predictions of a Thermodynamic Equilibrium Model. Energy Fuels 2002, 16, 956-963. [CrossRef]

108. Verhulst, A.D.; Buekens, A.; Spencer, P.J.; Eriksson, G. Thermodynamic Behavior of Metal Chlorides and Sulfates under the Conditions of Incineration Furnaces. Environ. Sci. Technol. 1996, 30, 50-56. [CrossRef] 